\title{
Taxonomic revision of the threatened African genus Pseudohydrosme Engl. (Araceae), with P. ebo, a new, critically endangered species from Ebo, Cameroon
}

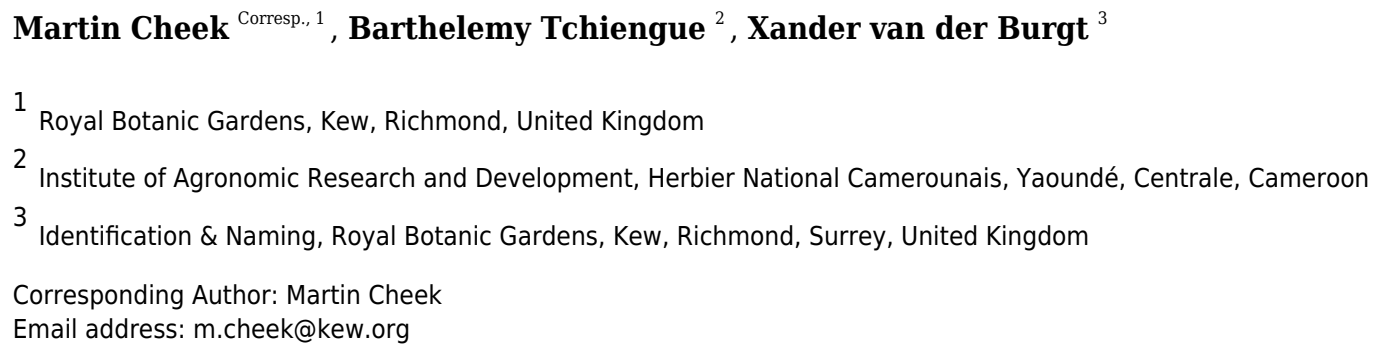

This is the first revision in more than 100 years of the African genus Pseudohydrosme, formerly considered endemic to Gabon. Closely related to Anchomanes, Pseudohydrosme is distinct from Anchomanes because of its 2-3-locular ovary (vs. unilocular), peduncle concealed by cataphylls at anthesis and far shorter than the spathe (vs. exposed, far exceeding the spathe), stipitate fruits and viviparous (asexually reproductive) roots (vs. sessile, roots non-viviparous), lack of laticifers (vs. laticifers present) and differences in spadix: spathe proportions and presentation. However, it is possible that a well sampled molecular phylogenetic analysis might show that one of these genera is nested inside the other. In this case the synonymisation of Pseudohydrosme will be required. Three species, one new to science, are recognised, in two sections. Although doubt has previously been cast on the value of recognising Pseudohydrosme buettneri, of Gabon, it is here accepted and maintained as a distinct species in the monotypic section, Zyganthera. However, it is considered to be probably globally extinct. Pseudohydrosme gabunensis, type species of the genus, also Gabonese but probably extending to Congo, is maintained in Sect. Pseudohydrosme together with Pseudohydrosme ebo sp.nov. of the Ebo Forest, Littoral Region, Cameroon, the first addition to the genus since the nineteenth century, and which extends the range of the genus $450 \mathrm{~km}$ north from Gabon, into the Cross-Sanaga biogeographic area. The discovery of Pseudohydrosme ebo resulted from a series of surveys for conservation management in Cameroon, and triggered this paper. All three species are morphologically characterised, their habitat and biogeography discussed, and their extinction risks are respectively assessed as Critically Endangered (Possibly Extinct), Endangered and Critically Endangered using the IUCN standard. Clearance of forest habitat for logging, followed by agriculture or urbanisation are major threats. Pseudohydrosme gabunensis may occur in a formally protected area and is also cultivated widely but 
infrequently in Europe, Australia and the USA for its spectacular inflorescences. 
1 Taxonomic revision of the threatened African genus

2 Pseudohydrosme Engl. (Araceae), with P. ebo, a new, Critically

3 Endangered species from Ebo, Cameroon.

4

5

6

10 Corresponding author:

12

13

14

15 


\section{ABSTRACT}

This is the first revision in more than 100 years of the African genus Pseudohydrosme, formerly considered endemic to Gabon. Closely related to Anchomanes, Pseudohydrosme is distinct from Anchomanes because of its 2-3-locular ovary (vs. unilocular), peduncle concealed by cataphylls at anthesis and far shorter than the spathe (vs. exposed, far exceeding the spathe), stipitate fruits and viviparous (asexually reproductive) roots (vs. sessile, roots non-viviparous), lack of laticifers (vs. laticifers present) and differences in spadix: spathe proportions and presentation. However, it is possible that a well sampled molecular phylogenetic analysis might show that one of these genera is nested inside the other. In this case the synonymisation of Pseudohydrosme will be required.

Three species, one new to science, are recognised, in two sections. Although doubt has previously been cast on the value of recognising Pseudohydrosme buettneri, of Gabon, it is here accepted and maintained as a distinct species in the monotypic section, Zyganthera. However, it is considered to be probably globally extinct. Pseudohydrosme gabunensis, type species of the genus, also Gabonese but probably extending to Congo, is maintained in Sect. Pseudohydrosme together with Pseudohydrosme ebo sp.nov. of the Ebo Forest, Littoral Region, Cameroon, the first addition to the genus since the nineteenth century, and which extends the range of the genus $450 \mathrm{~km}$ north from Gabon, into the Cross-Sanaga biogeographic area.

The discovery of Pseudohydrosme ebo resulted from a series of surveys for conservation management in Cameroon, and triggered this paper. All three species are morphologically characterised, their habitat and biogeography discussed, and their extinction risks are respectively assessed as Critically Endangered (Possibly Extinct), Endangered and Critically Endangered using the IUCN standard. Clearance of forest habitat for logging, followed by agriculture or urbanisation are major threats. Pseudohydrosme gabunensis may occur in a formally protected area and is also cultivated widely but infrequently in Europe, Australia and the USA for its spectacular inflorescences. 


\section{INTRODUCTION}

94 The new species reported in this monograph was discovered as a result of a long-running survey 95 of plants in Cameroon to support improved conservation management. The survey is led by 96 botanists from the Royal Botanic Gardens, Kew and the National Herbarium of Cameroon-IRAD 97 (Institute for Research in Agronomic Development), Yaoundé. This study has focussed on the 98 Cross-Sanaga interval (Cheek et al., 2001) which contains the area with the highest species 99 diversity per degree square in tropical Africa (Barthlott et al., 1996). The herbarium specimens 100 collected in these surveys formed the foundations for a series of Conservation Checklists (see 101 below). So far, they have resulted in the discovery and publication of over 100 new species and 102 several new genera, the recognition of new protected areas and the production of scientific data

103 for the Cameroon Important Plant Area programme (https://www.kew.org/science/our-

104 science/projects/tropical-important-plant-areas-cameroon ).

106 In October 2015 the last two authors found two leafless, flowering plants of a spectacular aroid 107 in the Ebo Forest of Littoral Region, Cameroon (van der Burgt 1888, Fig. 1). Since these had 108 prickles on the peduncle they were provisionally identified as Anchomanes Schott. 
110 In late 2018 the herbarium specimen of this collection was redetermined by the first author as

111 Pseudohydrosme Engl., an erstwhile Gabonese genus previously unknown from Cameroon.

112 Pseudohydrosme is distinguished from Anchomanes by a peduncle much shorter than the spathe

113 (vs.far longer) and by 2-3-locular (vs.unilocular) ovaries (Mayo et al. 1997). Van der Burgt

1141888 was suspected of representing a species new to science since it differed in several

115 characters from the two known species of Pseudohydrosme. In addition, Ebo in Cameroon is

116 geographically $450 \mathrm{~km}$ distant from the range of those two previously known species in Gabon,

117 and is in a different biogeographic zone. In order to obtain the missing stages of fruit and leaf to

118 complement van der Burgt 1888, it was decided to revisit the collection site at the next available

119 opportunity. Hence, in December 2019 leaves, although not fruits, and additional field data were

120 obtained (van der Burgt 2377, Fig. 2) including from a further site. Additional characters

121 separating the Ebo taxon from other members of the genus were discovered in the newly

122 collected material. Early in 2020 a previously overlooked flowering specimen, Morgan 25 came

123 to light.

124

125 Pseudohydrosme was described by A. Engler with two species, P. gabunensis Engl. based on

126 Soyaux 299 (B) collected 13 Oct. 1881, and P. buettneri Engl. based on Büttner (Buettner) 519

127 (B) collected in Sept. 1884, both from forest at Sibang, formerly near and now largely subsumed

128 by, Libreville, the capital and principal city of Gabon (Engler 1892, Bogner 1981).

129

130 In 1973 the renowned aroid specialist Josef Bogner visited Gabon and rediscovered two plants of

$131 P$. gabunensis. Tubers were taken to Germany and cultivated allowing description of the leaves

132 of Pseudohydrosme for the first time (Bogner, 1981).

133

134

135

136

137

138

139

140

141

142

143

144

145

146

147

148

The second species of the genus, $P$. buettneri has never been refound. It differs so greatly from the first in the structure of its inflorescence (see key and species account below) that the noted aroid specialist N.E. Brown erected a separate genus, Zyganthera N.E. Brown for it (ThistletonDyer, 1901). Engler (1911) reduced Zyganthera to sectional rank within Pseudohydrosme.

In their monumental account 'The Genera of Araceae', Mayo et al. (1997) placed Nephthytis Schott as sister to Pseudohydrosme + Anchomanes, in the tribe Nephthytideae Engl. Molecular phylogenetic analysis has subsequently supported the close relationship of Pseudohydrosme and Anchomanes, but since each were represented by only a single taxon, it was not possible to test their monophyly or sister relationship (Cabrera et al., 2008; Cusimano et al. 2011; Nauheimer et al.,2012). In presenting new data on Pseudohydrosme gabunensis based on successful pollination of flowers and fruit production on plants in cultivation in the Netherlands, Hetterscheid \& Bogner (2013) questioned the distinction of Pseudohydrosme and Anchomanes. They considered the only difference to be the locularity of the ovaries (2-3 versus 1$)$ and set aside the difference in peduncle: spathe proportions maintained in Mayo et al. (1997). However, later in their paper Hetterscheid \& Bogner (2013) then brought to light two new characters that further support the distinction of Pseudohydrosme from both Anchomanes and from all other aroids (see discussion below). Hetterscheid \& Bogner (2013) made the case to extend the range of Pseudohydrosme gabunensis from Gabon southwards into the Republic of Congo (CongoBrazzaville) citing photos and a specimen deposited at WAG by Ralf Becker. However, we have not been able to access the material in order to verify this statement (see methods). Despite this, 
155 we accept this record since it is confirmed by Alistair Hay (in litt.) who has seen it in flower and

156

157

158

159

160

161

162

163

164

165

166

167

168

169

170

171

172

173

174

175

176

177

178

179

180

181

182

183

184

185

186

187

188

189

190

191

192

193

194

195

196

197

confirms that it conforms to Pseudohydrosme gabunensis in spathe shape and colour.

In this paper we describe the Cameroon material from Ebo Forest as a new species to science, Pseudohydrosme ebo Cheek, in the context of a revision of the genus, last revised over 100 years ago (Engler 1911).

\section{MATERIALS \& METHODS}

The electronic version of this article in Portable Document Format (PDF) will represent a published work according to the International Code of Nomenclature for algae, fungi, and plants (ICN), and hence the new names contained in the electronic version are effectively published under that Code from the electronic edition alone. In addition, new names contained in this work which have been issued with identifiers by IPNI will eventually be made available to the Global Names Index. The IPNI LSIDs can be resolved and the associated information viewed through any standard web browser by appending the LSID contained in this publication to the prefix "http://ipni.org/". The online version of this work is archived and available from the following digital repositories: PeerJ, PubMed Central, and CLOCKSS.

The fieldwork in Cameroon was conducted under the terms of the Memorandum of Collaboration between IRAD-Herbier National de Cameroun and Royal Botanic Gardens, Kew that is valid until $5^{\text {th }}$ Sept. 2021. The research permit number for the last author in 2019 was 000146/MINRESI/B00/C00/C10/C12 (issued 28 Nov 2019), and the export permit number was 098/IRAD/DG/CRRA-NK/SSRB/12/2019 (issued 19 Dec 2019). In 2015 the respective numbers were: 00076/MINRESI/B00/C00/C10/C14 (issued 25 Aug 2015) and 103/IRAD/DG/CRRANK/SSRB-HN/10/2015 (issued 23 Oct 2015). Fieldwork was approved by the Institutional Review Board of the Royal Botanic Gardens, Kew entitled the Overseas Fieldwork Committee (OFC) under the registration numbers OFC 673-1 (2015) and OFC 807-3 (2019). The most complete set of duplicates for all specimens made was deposited at YA, the remainder exported to $\mathrm{K}$ for identification and distribution following standard practice (Cheek \& Cable, 1997).

Herbarium citations follow Index Herbariorum (Thiers et al., 2020). Specimens were viewed at $\mathrm{B}, \mathrm{BR}, \mathrm{K}, \mathrm{P}, \mathrm{WAG}$, and YA. Pseudohydrosme is centred in Gabon. The national herbarium of Gabon is LBV, but the most comprehensive herbaria for herbarium specimens of that country are $\mathrm{P}$ and WAG. The National Herbarium of Cameroon, YA, was also searched for additional material but without success. During the time that this paper was researched, it was not possible to obtain physical access to material at WAG (due to the transfer of WAG to Naturalis, Leiden, subsequent construction work, and covid-19 travel and access restrictions). However, images for WAG specimens were studied at https://bioportal.naturalis.nl/?language=en and those from $\mathrm{P}$ at https://science.mnhn.fr/institution/mnhn/collection/p/item/search/form?lang=en US. We also searched JStor Global Plants (2020) for additional type material of the genus, and finally the Global Biodiversity Facility (GBIF, www.gbif.org accessed 23 Aug 2020) which lists 28 occurrences and 21 images, mainly relating to the holdings (including duplicate herbarium sheets) of WAG, followed by P.

Peer) reviewing PDF | (2020:10:53447:1:1:CHECK 2 Dec 2020) 
198 Binomial authorities follow the International Plant Names Index (IPNI, 2020). The conservation

199 assessment was made using the categories and criteria of IUCN (2012). GeoCAT was used to

200 calculate Red List metrics (Bachman et al., 2011). Spirit preserved material was not available.

201 Herbarium material was examined with a Leica Wild M8 dissecting binocular microscope fitted

202 with an eyepiece graticule measuring in units of $0.025 \mathrm{~mm}$ at maximum magnification. The

203 drawings were made with the same equipment using Leica 308700 camera lucida attachment.

204 This was used to characterise and measure in particular features of the flowers. The herbarium

205 specimens of the new species described below as Pseudohydrosme ebo were soaked in warm

206 water to enable the spathe to be folded back, exposing the spadix and hydrated flowers. The

207

208

209

210

211

212 RESULTS terms and format of the description follow the conventions of Mayo et al. (1997). Georeferences for specimens lacking latitude and longitude were obtained using Google Earth (https://www.google.com/intl/en uk/earth/versions/). The map was made using SimpleMappr (https://www.simplemappr.net).

\section{TAXONOMIC TREATMENT}

214 Pseudohydrosme is closely related to Anchomanes Schott (7-8 species) and the pair are in a sister relationship with Nephthytis Schott (6 species). Together these three genera are all tropical Africann (all are absent from Madagascar). However, anomalous Nephthytis bintuluensis A.Hay, Bogner \& P.C. Boyce occurs in Borneo (Hay et al,. 1994; Nauheimer et al., 2012). These three

Pseudohydrosme Engl. (Engler 1892: 455; Brown in Thistleton-Dyer 1901: 160; Engler 1911: genera comprise the Nephthytideae which is sister to the SE Asian tribe Aglaonemateae Engl. (Cabrera et al., 2008), consisting of Aglaonema Schott (Van et al., 2020). Both groups share adjacent male and female flower zones, free stamens, and collenchyma arranged in threads peripheral to the vascular strands of leaf blades and petioles (with the exception of Nephthytis, in which collenchyma can form interrupted bands (Keating, 2002; Cabrera et al., 2008).

Morphological support for Nephthytideae is the well-developed posterior costa, i.e., \pm tripartite primary development (Cusimano et al. 2011: Table 1)

Dracontioid leaf divisions characterise Pseudohydrosme and Anchomanes but are not present in Nephthytis. They derive from complex splitting of a 'simple' and virtually entire blade as the leaf unfurls after emergence, which is why the leaflets at the margin are truncate with two 'tips'. This is unique to Pseudohydrosme/Anchomanes (Hay. 2019: 285). Differences between Pseudohydrosme and Anchomanes are re-assessed in the discussion below.

233

234

235

236 47; Mayo et al., 1997: 221-222)

Type species: Pseudohydrosme gabunensis Engl. (Lectotypified by N.E.Brown in ThistletonDyer 1901:160).

Zyganthera N.E. Br. (Brown in Thistleton-Dyer, 1901:160). Heterotypic synonym.

Type and only species: Pseudohydrosme buettneri Engl. (Engler, 1892).

240 
241 Large, seasonally dormant, monoecious herbs. Rhizome shallowly subterranean, the growing point at ground level, subglobose or cylindrical with annular leaf scars, and erect to horizontal or obliquely inclined, growing continuously and not renewed with each growing period. Roots fleshy, produced along length of rhizome, sometimes reproductive (the distal ends rising to the surface and producing new plants). Leaf solitary, large, emerging from several cataphylls; petiole cylindrical, erect, long, with minute and sparse prickles, sheath very short and inconspicuous. Blade transitioning from simple, sagittate and entire in seedlings, leaves of older plants developing slits and divisions (see above), in mature plants leaves dracontoid : trisect, primary divisions pinnatisect, distal lobes mostly truncate and bifid, sessile and decurrent, proximal lobes acuminate; primary lateral veins of ultimate lobes pinnate, often forming a regular submarginal collective vein $(P . e b o)$ or an irregular collective vein, or veins running into margin (often in $P$. gabunensis), higher order venation reticulate.

Inflorescence solitary, appearing separately from the leaf. Cataphylls papery-membranous, (34-6, proximal \pm triangular, small, distal oblong-elliptic, exceeding spathe tube, pink-brown or red-brown, sometimes (P. gabunensis) spotted white. Peduncle concealed by cataphylls at anthesis, terete, very short $<1 / 10$ th the length of the spathe, with minute, sparse, prickles. Spathe large, fornicate, , unconstricted, / very broad, with flaring auriculate margins; tube convolute, fleshy, obconic, with a few sparse prickles on the outer surface proximally. Spadix short, about 1/10-1/4 length of spathe, sessile, female zone subcylindric (P.ebo) obconic (P.buettneri) or gently obconic or conic (P.gabunensis), male zone cylindric, obtuse or rounded, subequal to \pm twice ( \pm four times in $P$. buettneri) as long as female, completely covered in flowers and fertile to apex (P. gabunensis) or with a distal appendix twice as long as the fertile portion and covered in sterile male flowers (P. buettneri) or flowers only laxly covering the spadix axis in the female zone and with the distal part of the axis of the female zone completely naked in places $(P . e b o)$.

Flowers unisexual, perigone absent. Male flower 2-5-androus, stamens free, subprismatic, compressed, anthers sessile, connective thick, broad, overtopping thecae, thecae oblong, long, lateral, dehiscing by apical pore. Pollen extruded in strands, inaperturate, ellipsoid-oblong, very large (mean 106 micrometres diam.) exine psilate to slightly scabrous. Sterile male flowers $(P$. buettneri) composed of subprismatic, free staminodes. Female flower ovary globose to broadly ellipsoid, usually prismatic, 2-3-locular, ovules 1 per locule, anatropous, funicle short, placentation axile, at base of septum, stylar region attenuate to cylindric, narrower than ovary, stigma thick, shallowly 2-3-lobed or subdiscoid, concave centrally, wet when receptive.

Infructescence with slightly accrescent peduncle. Berry at first white, ripening dark purple, fleshy, wrinkled when mature, oblong-ellipsoid, laterally compressed to slightly bilobed, stipitate, large; stigma and style persistent (known only in P. gabunensis). Seeds subglobose to broadly ovoid, one side convex, the other slightly flattened, testa thin, whitish, smooth, papery, transparent; embryo large, outer surface green, inner white, endosperm absent, raphe distinct, hilum and micropyle purple, plumule with leaf primordia. Three species.

This description is based on that of Mayo et al.(1997), with the addition of descriptions of the fruit, seed and roots of $P$. gabunensis, mainly from (Hetterscheid \& Bogner, 2013), with novel features of the nervation, spathe and spadix from $P$. ebo (below in this paper)

Phenology: flowering Sept. and Oct. (or March in cultivation in Europe); in leaf Dec.-April. 
287 Distribution \& habitat: Cameroon, Gabon and Congo(Brazzaville), lowland evergreen forest

288

289

290

291

292

293

294

295

296

297

298

299

300

301

302

303

304

305

306

307

308

309

310

311

312

313

314

315

316

317

318

319

320

321

322

323

324

325

326

327

328

329

330

331

332 on coastal sediments (Gabon) or inland foothills on basement complex rocks (Cameroon) (Fig. 3). Etymology: meaning "false Hydrosme", Hydrosme Schott is a synonym of Amorphophallus. Local name and uses: none are documented.

Conservation: all species are highly infrequent and globally threatened according to IUCN (2012) criteria (see species accounts below), and P. buettneri is possibly extinct (not seen for over 100 years, the majority of its former habitat destroyed).

Pollination in the wild has not been investigated in detail in Pseudohydrosme, but is almost certainly by insects as is usual in Araceae. Two different species of flies, and two of beetles were reported to visit $P$. gabunensis (see below). In cultivation the stigmas are reported to be wet and receptive for only two days, and the scent reported to be faint, of lettuce (Lactuca) in the same species (see below also). Following successful fertilisation, seed development is reported to take up to 10 months in P. gabunensis (see below). Seed dispersal is probably by either grounddwelling mammals or birds consuming the thinly fleshy purple berries.

DNA analysis was performed by Cabrera et al. (2008) for Pseudohydrosme gabunensis, using five regions of coding $(r b c L, m a t K)$ and noncoding plastid DNA (partial trnK intron, $t r n L$ intron, $\operatorname{trn} L-\operatorname{trn} F$ spacer). These sequences were subsequently used by Cusimano et al (2011) and Nauheimer et al. 2012). The voucher is Wieringa 3308 (WAG), identified by Hetterschied, GenBank codes are AM905760, AM920582, AM932319 + AM933315.

Cultivation of one species, Pseudohydrosme gabunensis is unknown in Africa yet widespread but infrequent in the tropical glass-house collections of several large extra-African botanical gardens, mainly in Europe, Australia and N. America (see under that species).

Chromosome numbers are reported of one species, Pseudohydrosme gabunensis, as $2 \mathrm{n}=\mathrm{ca} .40$ (Mayo et al., 1997).

Germination in Pseudohydrosme gabunensis is cryptocotylar and takes 3 weeks to 10 months. The large seed embryo remains buried, producing a single hastate seedling leaf (Hetterscheid \& Bogner, 2013). The seedling type is C2 in the classification of Tillich (2014).

Medicinal uses, and chemistry is unreported in Pseudohydrosme. However, the much more frequent sister genus Anchomanes, is harvested as a traditional medicine e.g. in Cameroon, and contains bioactive compounds (Cheek, 1992)

\section{Identification key to the sections and species of Pseudohydrosme}

1. Spadix with distal half covered in sterile male flowers. Sect. Zyganthera .........1. P. buettneri

1. Spadix lacking sterile flowers, distal part with fertile male flowers only. Sect. Pseudohydrosme...2 
333 2. Male and female zones of spadix contiguous; entire spadix covered in flowers densely

334 arranged in both male and female zones; spathe blade inner surface yellow, greenish yellow or 335 white with abrupt transition to a central dark red area;

336 stigmas 2(-3)-lobed. Gabon (probably Congo-Brazzaville) 2. P. gabunensis

337

338

339

340

341

342

343

344

345

346

347

348

349

350

351

352

353

354

355

356

357

358

359

360

361

362

363

364

365

366

367

368

369

370

371

372

373

374

375

376

377

378

2. Male and female areas of spadix incompletely contiguous; female flowers laxly arranged with axis of female zone partly naked especially distally; spathe blade inner surface light reddish brown or pink, with wide green veins, very gradually becoming darker towards the centre; stigmas 3(-2)-lobed.

Cameroon

3. P. ebo

Sect. Zyganthera (N.E.Br.) Engl. (Engler 1911: 49)

Type (and only) species: Pseudohydrosme buettneri Engl.

Zyganthera N.E. Br. (Brown in Thistleton-Dyer, 1901:160). Basionym

Male flowers with stamens in pairs; distal half of spadix covered in sterile male flowers; ratio of female:male (including sterile male) spadix portions c. $1: 4$

1. Pseudohydrosme buettneri Engl. (Engler 1892:456; Engler 1897: 59; Brown in ThistletonDyer 1901: 160; Engler 1911: 49). - Fig. 3, 4.

Holotype: Gabon, Estuaire Province, Libreville “Gabun, Mundagebiet; Sibange-Farm” fl. Sept. 1884, Buettner 519 (Holotype B destroyed or mislaid).

Terrestrial herb, rhizome vertical, subglobose, $2.5 \mathrm{~cm}$ long, $2.5 \mathrm{~cm}$ wide, surface tuberculate, roots fleshy, from along the length of the rhizome. Leaf unknown.

Inflorescence: Cataphylls three or more, 2-13 x 0.9-1 cm; peduncle $3 \mathrm{~cm}$ long, colour and indumentum unknown. Spathe $80 \mathrm{~cm}$ long, within pale except for the median longitudinal part which is dark purple. Spadix subcylindrical, $7-8 \mathrm{~cm}$ long, c. $1.3 \mathrm{~cm}$ diam. Female zone obconic $1.3 \mathrm{~cm}$ long. Fertile male zone $2 \mathrm{~cm}$ long. Appendix (of sterile male flowers) $5 \mathrm{~cm}$ long, c. 1.5 cm diam.

Female flowers $4 \mathrm{~mm}$ long, ovary globose-ovoid, $3 \mathrm{~mm}$ diam., style $1 \mathrm{~mm}$ long, slender; stigma bilobed, $1 \mathrm{~mm}$ diam., thick; ovules shortly ovoid, solitary in each locule and attached near the base of the septum. Male flowers with stamens $2 \mathrm{~mm}$ long, $2 \mathrm{~mm}$ wide, usually the two stamens of a flower, appressed to one another, with bilocular subextrorse thecae nearly reaching the stamen apex. Staminodes subprismatic, 4-6 sided, lacking anther thecae and much smaller in diameter than the stamens (description taken from Engler (1892:456 and tab. XV).

Phenology: flowering in September.

Local name and uses: none are known. 
379 Etymology: named for the collector of the only known, and type specimen, Oscar Alexander

380

381

382

383

384

385

386

387

388

389

390

391

392

393

394

395

396

397

398

399

400

401

402

403

404

405

406

407

408

409

410

411

412

413

414

415

416

417

418

419

420

421

422

423

424

Richard Buettner (Büttner) - (1858-1927), traveller and collector.

Distribution \& ecology: known only from Sibang in Libreville, coastal lowland evergreen forest dominated by Aucoumea klaineana Pierre.

Additional specimens: none are known.

Notes: Pseudohydrosme buettneri has the largest inflorescence by far of all known species of the genus, with an $80 \mathrm{~cm}$ long spathe (however, $70 \mathrm{~cm}$ has been reached for $P$. gabunensis in cultivation in Australia according to Hay in litt.). The type specimen had lost the top part of the spathe, but dimensions were given by the collector (Engler, 1892).

The type, and only known specimen was at B, but is reported to be no longer there (Bogner 1981). It may have been lost in the allied bombing of Berlin in March 1943, when most of the specimens at B were destroyed. However, the type specimen of P. gabunensis (see below) dating from about the same time, and also housed at B, has survived.

No additional specimens of this species have been found in the 136 years ensuing from collection of the type specimen. Hetterscheid \& Bogner (2013) have questioned whether this species is not just a variant of $P$. gabunensis. However, this seems highly unlikely, because the specimen differs in three independent characters from P. gabunensis (and P. ebo):

1) the ratio between the female zone and the male zone (of fertile and sterile flowers) differs greatly between the two. In P. buettneri the ratio is 1:4+, while in the other two species it is less than 1:2.

2) in $P$. buettneri most of the spadix consists of an appendix of sterile male flowers. No such sterile appendix occurs in the other two species. In fact this character is otherwise unknown in the entire Aglaonemateae/Nephthytideae clade

3) in P. buettneri the stamens are paired (Engler 1892), while in the other two species the stamens are not reliably paired, but also present in an indistinct ring of three to five.

Additional differences between the species can be seen in the pistil and spadix. The style in $P$. buettneri is $<1 / 4$ the width of the ovary. In $P$. gabunensis it is $1 / 2$. The spadix of $P$. buettneri is cylindrical, and unconstructed, while that of $P$. gabunensis shows a pronounced constriction at the junction of female and male zones, and the male zone attains a greater width than the female zone.

Conservation. Pseudohydrosme buettneri is here assessed as Critically Endangered (Possibly Extinct). This is because it has only been found once, at a single site, in the "Munda region" at Sibang Farm or Plantation, in 1884. At that time Sibang was far outside Libreville and consisted largely of forest, some of which was exploited to produce forest products such as timber and rubber, and cleared to produce agricultural products by Europeans for international commerce e.g. by the Woermann company (Cheek et al. 2011: 45). The Munda is the estuary that forms the eastern edge of the peninsula on which Libreville sits. Tributaries of the Munda drain the Sibang area. Beginning in 1960, the population of Libreville expanded 200 -fold, and its footprint

Peer) reviewing PDF | (2020:10:53447:1:1:CHECK 2 Dec 2020) 
425

426

427

428

429

430

431

432

433

434

435

436

437

438

439

440

441

442

443

444

445

446

447

448

449

450

451

452

453

454

455

456

457

458

459

460

461

462

463

464

465

466

467

468

469

470

expanded. Only a small part of the original forest formerly known as Sibang survived. This part measures about $400 \mathrm{~m} \times 400 \mathrm{~m}$ as measured on Google Earth (see further details under $P$. gabunensis, below) and is now entitled the 'Sibang Arboretum'. This minute remnant of forest is probably the most visited by botanists in the whole of Gabon because it is immediately adjacent to the site of the current National Herbarium, LBV (Cheek, pers. obs.). In the unlikely although hoped-for rediscovery of Pseudohydrosme buettneri, the area of occupancy would be expected to be calculated as $4 \mathrm{~km}^{2}$ using the IUCN preferred gridcells of this size, and the extent of occurrence of the same size. If it should be found anywhere in the vicinity of Libreville it is likely to be threatened by human pressures since most of the population of Gabon is concentrated here.

The Libreville region has the highest botanical specimen collection density in Gabon, with 5359 specimens recorded in digital format. It also has the highest level of diversity of both plant species overall and of endemics (Sosef 2005). The coastal forests of the Libreville area are known to be especially rich in globally restricted species (Lachenaud et al. 2013). These authors detail 19 species globally restricted to the Libreville area, of which eight have not been seen recently and which are possibly extinct. Among these is Octoknema klaineana Pierre, a rainforest tree "only collected in the immediate area of Libreville at the beginning of the $20^{\text {th }}$ century, and only once since." (Gosline \& Malecot, 2011). Most of the collections of this possibly extinct species of Octoknema were also, as with Pseudohydrosme buettneri, from Libreville-Sibang, and were mainly made in the period 1896-1912, during the colonial period, before the city expanded to its current extent. The other seven species recorded as globally restricted to the Libreville area and as possibly extinct by Lachenaud et al. (2013): are Ardisia pierreana Taton (Taton,1979), Dinklageella villiersii Szlach. \& Olszewski (Szlachetko \& Olszewski, 2001), Eugenia librevillensis Amshoff (Amshoff, 1958), Hunteria hexaloba (Pichon) Omino (Omino, 1996), Pandanus parvicentralis Huynh (Huynh, 1986), Psychotria gaboonensis Ruhsam (Ruhsam et al. 2008) and Tristemma vestitum Jacq.-Fél. (Jacques-Félix, 1986). These species have also not been seen in several decades, or more, in the case of the penultimate species, since 1861.

The explanation for this hotspot of unique species, fast disappearing if not already extinct, at Libreville may be that it has the highest rainfall in Gabon (Gosline \& Malecot, 2011), with c.2.9 m p.a.

It seems likely that Pseudohydrosme buettneri is an additional lost endemic species to the Libreville area, likely rendered extinct by the expansion of the city. Let us hope it is rediscovered in a fragment of forest in the greater Libreville area, although this seems extremely unlikely given that it was the most spectacular species of the genus with by the largest spathe ( 80 $\mathrm{cm}$ long) known in the genus, and that as stated above, the Libreville area is the most intensively botanically surveyed part of Gabon (Sosef et al., 2005).

\section{Sect. Pseudohydrosme}

Pseudohydrosme Engl. Sect. Chorianthera Engl. (Engler, 1911: 48). Homotypic synonym Type species: Pseudohydrosme gabunensis Engl. 
471

472

473

474

475

476

477

478

479

480

481

482

483

484

485

486

487

488

489

490

491

492

493

494

495

496

497

498

499

500

501

502

503

504

505

506

507

508

509

510

511

512

513

514

515

Male flowers in indistinct clusters of 3-5 or in pairs; distal half of spadix lacking sterile male flowers; ratio of female:male spadix portions 1:2

2. Pseudohydrosme gabunensis Engl. (Engler, 1892:455; Engler 1897:59; Brown, 1907:161; Engler, 1911:48; Bogner, 1981:33; Hetterscheid \& Bogner, 2013:104-113). - Fig. 3, 5.

Holotype: Gabon, Estuaire Province, Libreville, Sibang, “Gabun, Mundagebiet; Sibang-Farm am Ufer des Maveli” fl. 13 October 1881, Soyaux 299 (Holotype: B100165306, Herbarium specimen, image!)

Terrestrial herb, rhizome light brown, ellipsoid or subcylindric, erect or oblique, 9-12 cm diam. to $15 \mathrm{~cm}$ long, surface with transverse ridges. Roots fleshy 5-8 $\mathrm{mm}$ thick, brownish yellow, sometimes developing new plants at their tips (Hetterscheid \& Bogner, 2013).

Leaf 1-1.3(-2.2) $\mathrm{m}$ tall, petiole terete, $1-1.4 \mathrm{~cm}$ diam. at base, dark green olive and spotted, with small yellowish white points; prickles 1-2 mm long. Blade of youngest seedlings sagittateelliptic c. $5 \mathrm{~cm}$ long, 3-4 cm wide, basal sinus c. $2 \mathrm{~cm}$ long, breadth variable (see Hetterscheid \& Bogner, 2013). Successively formed blades developing slits and divisions. Blade of mature leaves dracontoid, primary divisions $30-35 \mathrm{~cm}$ long, pinnatisect, lobes in each division 5-8, dimorphic, larger, distal lobes elliptic (4-)8-23 cm long, (2-)3-7(-11) cm, apex truncate, bifid, (0.5-)1-3 cm long; smaller, proximal leaflets ovate, $4.5-8 \mathrm{~cm}$ long, $2.5-5 \mathrm{~cm}$ wide, apex cuspidate; lateral veins 4-8 on each side of the midrib, conspicuous on abaxial surface, running to the margin or forming an incomplete submarginal nerve, higher order veins reticulate.

Inflorescence: Cataphylls 4-6 membranous, reddish white or brown-purple, slightly spotted, phyllotaxy spiral, proximal ones subtriangular shorter, distal ones becoming longer and oblong elliptic, towards the spathe $1.5-29 \mathrm{~cm}$ long, (1-)2-2.5 cm wide; peduncle (3-)5-9 cm long, $1-$ $1.5 \mathrm{~cm}$ diam., colour as petiole, with minute sparse greenish white prickles $1-2 \mathrm{~mm}$ long. Spathe (30-)40-55(-70) cm long, fornicate, basal half (20-25 cm long) funnel-shaped to subcylindrical, fleshy and to $5 \mathrm{~mm}$ thick, limb comprising the distal half of the spathe, flaring widely and curving forward, the apex obtuse, margin undulate; outer surface uniform bright pale yellow, greenish yellow or yellow white; inner surface of blade mostly pale yellow or yellowish white, in an irregular marginal band, with a dark purple central area separated by an irregular margin down to the base of the tube; mouth facing horizontally, usually orbicular or elliptic. Spadix with "unpleasant smell, but not so strong as some Araceae" (van der Laan 7641, WAG) or "faintly of lettuce" (Hetterscheid and Bogner (2013)) or "of slightly bad cabbage" (David Prehsler, University of Vienna communication to Cheek Nov. 2020), sessile, subcylindrical, (6-)9-12.5 cm long, (1.5-)2-2.5 cm diam. Female zone (2-)3.5(-4) cm long, female flowers completely covering the surface of the axis, usually contiguous with but constricted at the junction with the male zone. Male zone (3.5-)6-8.5 cm long, at base abruptly wider than the female zone, tapering to the rounded apex, completely covered in fertile male flowers. Sterile appendix absent.

Peer) reviewing PDF | (2020:10:53447:1:1:CHECK 2 Dec 2020) 
516 Male flowers with 2-5 stamens, stamens densely packed, sometimes paired or in groups of 3 or 5, 517 sessile, $4 \mathrm{~mm}$ long, in plan view isodiametric, subprismatic, 5-6-faceted, in cross section c. 1.8(518 2) $\mathrm{mm} \times 1.2 \mathrm{~mm}$ wide, apex convex purple, sides white, anther thecae c. $3 \mathrm{~mm}$ long, opening by 519 an apical pore, pollen orange or yellow, in strings. Female flowers white with ovary yellowish520 white globose or ellipsoid, 2-3 mm diam., 2(-3)-locular; style 1-1.5 mm long, $1.5 \mathrm{~mm}$ diam., 521 stigma black to reddish brown, surface papillose, $2 \mathrm{~mm}$ wide, bilobed, lobes with a broad 522 concave area, apex rounded.

523

524

525

Berry, thinly fleshy, transversely ellipsoid, laterally compressed, rarely globose, $0.8-1.2 \mathrm{~cm}$ long, 1.5-1.6 cm wide, white, ripening purple-black, surface wrinkled when ripe, style and stigma persistent, (1-)2-seeded, apex rounded-truncate, base stipitate, stipes (2-)3-4 mm long, c. $2 \mathrm{~mm}$ diam. Seeds subglobose to broadly ellipsoid, one side flattened, the other convex, $9 \mathrm{~mm}$ long, 7 mm wide.

529

530

531

532

533

534

535

536

537

538

539

540

Phenology: flowering in the wild mid-Sept.-late Oct.

Distribution \& ecology: Gabon, Estuaire, Moyen-Ogooué (probably) and Woleu-Ntem Provinces, known from five sites in lowland rainforest sometimes with Aucoumea gabonensis (Burseraceae); 0-100 m alt. Possibly also in Congo (location unknown, see notes below).

Etymology: meaning “coming from Gabon” (formerly, in German "Gabun”).

Local names \& uses: none known.

Additional specimens: Gabon, Woleu-Ntem Province, c. 15 km NE Asok, 600-700 m alt., (leg. Breteler \& de Wilde s.n. 21 Aug. 1978) cult. Wageningen, fl. 13 March 1984, van der Laan

542

543

544 764 (Bot. Gard. No. 978PTGA550), WAG0351246, WAG0351247 images!); Estuaire Province, Libreville, Sibang: "Sibang, hinter der Station forêstier; wächst im sandigen Lehmboden im Regenwald, sehr schattig, c. 20 m, fl. 29 Ocktober 1973, Bogner 664 (K!, M n.v. US n.v.); Sibang, st. 10 April 1994, Wieringa \& Haegens 2710 (WAG0181636, WAG0181637 images!);

546 Sibang Forest, st. 1 Dec. 1994, Wieringa 3308 (WAG0181631, WAG0181632, WAG 0181633,

547

548 WAG0181634, WAG0181635 images!); Sibang Arboretum fl. 25 Oct. 2005, Sosef et al. 2029 (WAG 0223594, WAG0223595 images!, WAG8004057, WAG0108030, WAG.1665445); 1006' 45.54'”E), fl. 2 Oct. 1912, Chevalier 26828 (P02093245 image!); Forêt de la Mondah, road from Libreville to Santa Clara, fl. 16 Sept. 1981, Breteler, Lemmens, Nzabi 7772 (WAG0449339, WAG0449339, WAG0449340 images!); St. Clara, Tussen \pm 50-100 m, Linkerkant, Zij-pod naar St. Clara, sterile, no date, Breteler s.n. (WAG044938, image!);

560 Those specimens listed above which are sterile, e.g. Wieringa 3308 (voucher for DNA studies of 561 the genus, see above), Wieringa \& Haegens 2710 , are only provisionally identified as $P$. 
562 gabunensis. It is possible that these specimens might belong to another species of the genus 563 (although unlikely since these specimens were collected at Sibang Arboretum where in recent 564 years only this species of the genus has been collected in flower). Equally they may even 565 represent a species of the genus Anchomanes.

566

567

568

569

570

571

572

573

574

575

576

577

578

579

580

581

582

583

584

585

586

587

588

589

590

591

592

593

594

595

596

597

598

599

600

601

602

603

604

605

606
Conservation: Pseudohydrosme gabunensis is possibly extinct at some of its historical locations and is threatened at all of those which remain. At the type location, Sibang, formerly far outside Libreville, at least four gatherings have been made in what is now a small and highly visited forest patch inside Libreville (see notes under P. buettneri above). Measured on Google Earth, the forest is approximately a square, c. $470 \mathrm{~m} \mathrm{~N}$ to S, and $420 \mathrm{~m} \mathrm{~W}$ to E, or about 0.25 $\mathrm{km}^{2}$ (grid reference: $0^{\circ} 25^{\prime} 56.05^{\prime} \mathrm{N}, 9^{\circ} 29^{\prime} 23.64^{\prime \prime} \mathrm{E}, 49 \mathrm{~m}$ alt.). It is now completely surrounded by the dense urban settlement of Libreville which has expanded greatly in the last 60 years. In 1960, at independence, the population of Libreville was 32,000. Since then it has expanded 200-fold to, in 2013, 703,904 (https://en.wikipedia.org/wiki/Libreville, accessed 19 Sept. 2020) and has a vastly greater footprint. Sibang Arboretum, the surviving patch of forest of a once much greater area, is now known as one of the top two tourist destinations in Libreville.

At the Cap Santa Clara location, the Forêt de la Mondah, known since 2012 as the Raponda Walker Arboretum (Walters et al. 2016), two collections were made, one in 1981 (see additional specimens). Since created as a protected area in 1934, it has been reduced in size, losing $40 \%$ of its area in 80 years to habitat clearance and degradation due to its close proximity (c. $15 \mathrm{~km})$ to the metropolis of Libreville which draws upon its trees for timber and firewood (Walters et al. 2016). It is not clear if either of the two specimens from St. Clara were from within the current protected area.

The species has not been recorded from the Ogouue River since it was collected there by Leroy (1894-1895), despite intensive recent surveys in the lower reaches of the river whence it was probably collected. We have georeferenced the Leroy record on Lambarene since in Leroy's time this was a trading post on the lower reaches of the river and it is credible that he stopped and collected there, but this is uncertain. The historic site on the Komo River at Kango, whence it was collected by Chevalier (26828, P; fl. 2 Oct. 1912) is now on a major transnational route, and on Google Earth shows multiple cleared areas due to development. It is possible that it no longer survives at this location, especially since it has not been recorded here or anywhere near, in a century, despite the peak decades of botanical collection in Gabon having been at the end of the $20^{\text {th }}$ century (Sosef et al. 2005). Pseudohydrosme gabunensis was assessed as Endangered, EN B2ab(ii,iii) by Lovell \& Cheek (2020) since it is or was known from ten specimens at five locations globally, with an area of occupation estimated as $24 \mathrm{~km}^{2}$ using the $4 \mathrm{~km}^{2}$ cell sizes preferred by IUCN (2012) and the threats detailed above. Threats in the Libreville area have already resulted in the possible global extinction of nine species, including Pseudohydrosme buettneri (see under that species, above). The extent of occurrence is calculated as $4,150 \mathrm{~km}^{2}$. If the identification of the Congolese specimen can be completely confirmed as this species, and the site of its collection discovered, the area of occupation will likely be increased to $28 \mathrm{~km}^{2}$, and the extent of occurrence also increased. 
607 Notes. The location given in the protologue for the type specimen (see above) is similar to that 608 of Pseudohydrosme buettneri but more detailed. The Munda is the estuary that forms the eastern 609 edge of the peninsula on which Libreville sits. Tributaries of the Munda drain the Sibang area,

610 one of which may have been known as the Maveli, on the forested banks of which Soyaux

611 recorded collecting the type of Pseudohydrosme gabunensis. Herman Soyaux is reported to have 612 collected herbarium specimens from Loango in Gabon from 1875-1882 (Anon, 1901).

613 The specimens Leroy 23 and Chevalier 26828 (both P) had been determined as Amorphophallus 614 until identified by Bogner (M) as Pseudohydrosme gabunensis in Dec. 2012. In contrast, 615 Wieringa 4358 (WAG) determined as this species, and cited as such in Sosef et al. (2005) is in 616 fact an Amorphophallus, evident in the larger leaf blade divisions all being acuminate not bifid, 617 and the tuber being described as having the roots from the top (vs.scattered along the length). 618 Similarly, Wieringa 3308 (WAG), correctly cited in Sosef et al. (2005) as Pseudohydrosme 619 gabunensis, was originally collected as an Anchomanes until determined by Hetterscheid in April 620 1996. Van der Laan 764 (WAG) had been identified as Anchomanes nigritianus Rendle until 621 redetermined by Bogner in Sept. 2012.

622

623

624

625

626

Pseudohydrosme gabunensis is the most common and widespread member of the genus. However, it is still extremely rare and with a highly restricted range in the wild. It is sought after by private collectors of aroids and live rootstocks and seed attract high prices on the internet. Fortunately, it is found in several large public botanic gardens including in Australia, Germany, France, Netherlands, U.K. and U.S.A. We believe that plants are probably not collected from the wild (but this cannot be ruled out), rather they are propagated from those already in cultivation, probably from seed derived from the Netherlands.

632

633

The collection reported in Hetterscheid and Bogner (2013) as from Congo must be treated with caution. Since it is greatly disjunct (at least c. $300 \mathrm{~km}$ ) from the known range of this species, it may even represent a further new species. We have not been able to view this specimen.

634 However, Hay (in litt.) states that he has seen photographs of flowering material and that it looks

635 extremely like $P$. gabunensis in terms of spathe shape and colouration, therefore this is the most

636

637

638

639 likely identification. The specimen concerned should be located, the spadix studied carefully to determine the species beyond doubt, and an attempt made to rediscover the source population.

Differences between Pseudohydrosme gabunensis and P. buettneri are detailed under the last

640 species. There is no doubt that Pseudohydrosme gabunensis is much more closely similar to $P$. ebo than to P. buettneri. However, the larger size of the spathes in P. gabunensis, their different colour and patterning, the usually bilobed style and bilocular female flowers densely covering

643

644 the axis, all serve, together with the vegetative characters, to separate it from P. ebo (see also table 1 below).

645

Floral visitors: Bogner (1981) collected as inferred pollinators two different flies identified as Diptera: Choridae, Sphaeroceridae, and two different beetles identified as Coleoptera:

651 Reproductive biology: Hetterscheid \& Bogner (2013:106) working with cultivated plants, report 652 that the female flowering phase is indicated by a faint yet clear lettuce-like scent as the spathe 
653 opens, at which time, for 2 days, the receptive stigmas are wet and sticky. After this time the 654 stigmas turn darker brown, desiccate and are no longer receptive. Individuals are obligate

655

656

657

658

659

660

661

662

663

664

665

666

667

668

669

670

671

672

673

674

675

676

677

678

679

680

681

682

683

684

685

686

687

688

689

690

691

692

693

694

695

696

697

698

outcrossers. Fruits take up 10 months to mature (Hetterscheid \& Bogner, 2013).

Germination and development: Germination takes 3 weeks to 10 months, producing a single small sagittate, entire leaf from a small rhizome. For several months to two years, new leaves are produced consecutively, usually each larger than its predecessor (Hetterscheid \& Bogner, 2013). From the second leaf onwards slits may develop in the blade, and within two years the successively produced blades first becomes divided and finally develop the mature dracontoid pattern (see description). First flowering has occurred in as little as five years from first sowing (Hetterscheid \& Bogner, 2013). In the wild, the time to maturity is likely to take longer due to predation, competition, and likely lower availability of nutrients

\section{Pseudohydrosme ebo Cheek, sp. nov. - Fig. 1-3, 6 \&7.}

Differing from Pseudohydrosme gabunensis Engl. in the ovaries 3-locular, the stigma conspicuously 3-lobed, very rarely 2-locular/lobed (vs. usually 2-locular, 2-lobed, rarely 3locaular/lobed), the female zone of the spadix only sparsely covered in flowers, the spadix axis visible between the flowers (vs. completely covered in flowers), the spathe at anthesis 24-30($34.5) \mathrm{cm}$ long, the outer surface dull white with longitudinal brown stripes, inner surface light reddish brown with wide pale green veins (vs.(30-)40-55(-70) cm long, uniformly white, green or yellow on both surfaces, inner surface bicoloured, the mid-limb area dark purple, sharply demarcated from the marginal white/yellow coloured area). Type: B.J. Morgan 25 (holotype K!; isotypes B! MO! YA!), Cameroon, Littoral Region, Yabassi-Yingui, Ebo proposed National Park, fl. Sept. 2010.

Terrestrial herb, to $1.55 \mathrm{~m}$ tall. Rhizome cylindric, c. $3 \mathrm{~cm}$ diam. obliquely erect to almost parallel to substrate surface, only upper part exposed, surface with transverse ridges (leaf scars) about $2 \mathrm{~mm}$ deep, $2 \mathrm{~mm}$ apart. Roots adventitious, thick, fleshy, c. $5 \mathrm{~mm}$ diam., scattered along length of rhizome, asexual reproduction not detected.

Leaf to $1.55 \mathrm{~m}$ tall, petiole terete, to $2 \mathrm{~cm}$. diameter at base, green, inconspicuously spotted yellow, mature plants with minute, patent, extremely sparse prickles $0.5 \mathrm{~mm}$ long. Blade of youngest seedlings sagittate-elliptic, $5 \times 2.5 \mathrm{~cm}$, apex obtuse, basal sinus $1.5 \times 1.5 \mathrm{~cm}$, petiole 6$7 \mathrm{~cm}$ long. Older seedlings, in successive years with leaves developing first slits and then divisions, becoming triangular in outline with a broad basal sinus. Blade of mature leaves dracontoid, primary division 35-40 x 38-43 cm, pinnatisect, lobes 5-8, dimorphic, larger, mainly distal lobes oblong $12.5-22 \times 3.8-6.5 \mathrm{~cm}$, apex acuminate or truncate-bifid (biacuminate), acumen $0.8-1.5 \mathrm{~cm}$ long, smaller, mainly proximal lobes ovate c. 8 x $3.5 \mathrm{~cm}$; lateral veins $6-11$ conspicuous on abaxial surface, on each side of the midrib, uniting to form a regular looping submarginal vein 3-6 $\mathrm{mm}$ from the margin, higher order veins reticulate.

Inflorescence: Cataphylls 4, phyllotaxy spiral, light brown, with light green spots, membranous, successively increasing in size from proximal to distal, the outermost triangular-broadly ovate, amplexicaul $3 \times 4 \mathrm{~cm}$, the third in succession narrowly lanceolate-oblong, $12 \times 2 \mathrm{~cm}$, the fourth $18-19 \times 1.5-4 \mathrm{~cm}$; peduncle $3.5-4.5 \times 0.6-0.7 \mathrm{~cm}$, with minute, patent, extremely sparse prickles

Peer) reviewing PDF | (2020:10:53447:1:1:CHECK 2 Dec 2020) 
$6990.5 \mathrm{~mm}$ long, colour as petiole. Spathe $24-30(-34.5) \times 8 \mathrm{~cm}$ long basal $1 / 2-3 / 4$ subcylindric, 700 convolute, funnel-shaped, $1.8-4 \mathrm{~cm}$ wide at $2 \mathrm{~cm}$ above the peduncle, $6-8 \mathrm{~cm}$ wide at $8 \mathrm{~cm}$

701

702

703

704

705

706

707

708

709

710

711

712

713

714

715

716

717

718

719

720

721

722

723

724

725

726

727

728

729

730

731

732

733

734

735

736

737

738

739

740

741

742

743

744

above the peduncle, and $8-9 \mathrm{~cm}$ wide at $15 \mathrm{~cm}$ above the peduncle, the distal part (limb), half to one third of the total spathe length, flaring widely and curving forward, hood-like, shielding the spadix, the apex with a triangular acumen 3-4 x $1 \mathrm{~cm}$; outer surface of both tube and limb dull white, with pale brown-red ribs running longitudinally along veins from base of tube to mouth of limb; inner surface of spathe light reddish brown, with wide pale green veins, gradually becoming slightly darker along the midline; mouth facing horizontally, transversely elliptic, 8 $10 \mathrm{~cm}$ high, 20-25 cm wide, margin entire. Spadix sessile, cylindrical 50-85 mm long, 10-18 $\mathrm{mm}$ diam. Female zone $24 \mathrm{~mm}$ long, $15-18 \mathrm{~mm}$ wide, female flowers sparsely scattered, c. 30 , laxly arranged, covering only about half the surface of the spadix axis, the axis visible between the flowers, sometimes not contiguous with the male zone, the axis then naked for up to $10 \mathrm{~mm}$. Male zone 37-55 mm long, 10-14 mm wide, apex rounded, completely covered in densely arranged male flowers, sterile appendix absent.

Male flowers with 2-5 stamens, sometimes paired or in groups of 3-5, stamens free, sessile, prismatic, $5 \mathrm{~mm}$ long, isodiametric in plan-view, 5-6 faceted, (1.5-)2 $\mathrm{mm}$ diam., apex convex, minutely papillate; anther thecae lateral, tetrasporangiate (Fig. 6F), oblong-elliptic, running the length of the stamen, with apical pore (Fig. 6E). Female flowers with ovary globose, $4 \mathrm{~mm}$ diam., 3-locular (Fig. 6I), very rarely 2-locular, style $1-1.5 \mathrm{~mm}$ long, $1 \mathrm{~mm}$ diam., stigma pale yellow, $0.5 \mathrm{~mm}$ thick, 2-2.25 mm wide, strongly 3-lobed (Fig. 7E), lobes with a narrow midline groove, apex rounded. Berry and seed not seen.

Distribution \& ecology: Cameroon, Littoral Region, known only from three sites at one location in the Ebo forest near Yabassi-Yingui, in late secondary and intact, undisturbed lowland evergreen forest on ancient basement complex geology, rainfall c. 3 m p.a., drier season OctoberMarch; 300-400 m alt.

Conservation: Pseudohydrosme ebo is known from only one location, with three sites along a section of valley $1.3 \mathrm{~km}$ long and only 50-100 mature individuals in total have been seen by the collectors (second and third authors). These sites are along former logging roads which have reverted to forest (third author pers. obs. 2019) as well as intact forest. In the fourteen years since 2006, botanical surveys have been made almost annually, at different seasons, over many parts of the formerly proposed National Park of Ebo. About 3000 botanical herbarium specimens have been collected, but despite the species being so spectacular in flower, with individual inflorescences lasting potentially two weeks (if they prove to be similar in phenology to those of P. gabunensis), this species has been seen nowhere else in the c. $2000 \mathrm{~km}^{2}$ of the Ebo Forest. However, much of this area has not been surveyed during the flowering season of the species, or not surveyed at all for plants. While it is likely that the species will be found at additional sites, there is no doubt that it is genuinely range restricted. Botanical surveys for conservation management in forest areas neighbouring Ebo resulting in thousands of specimens being collected and identified have failed to find any specimens of Pseudohydrosme (Cheek et al. 1996; Cable \& Cheek 1998; Cheek et al. 2000; Harvey et al. 2004; Cheek et al. 2004; Cheek et al. 2010; Harvey et al. 2010). It is possible that the species is unique to Ebo and truly localised. The area of occupation of Pseudohydrosme ebo is estimated as $4 \mathrm{~km}^{2}$ using the IUCN preferred cell-size. The extent of occurrence is the same area. In February 2020 it was discovered that

Peer) reviewing PDF | (2020:10:53447:1:1:CHECK 2 Dec 2020) 
745

752

753

754

755

756

757

758

759

760

761

762

763

764

765

766

767

768

769

770

771

772

773

774

775

776

777

778

779

780

781

782

783

784

785

786

787

788

789

790

moves were in place to convert the forest into two logging concessions (e.g.

https://www.globalwildlife.org/blog/ebo-forest-a-stronghold-for-cameroons-wildlife/ and https://blog.resourceshark.com/cameroon-approves-logging-concession-that-will-destroy-eboforest-gorilla-habitat/ both accessed 19 Sept. 2020).

This would result in logging tracks that would allow access throughout the forest allowing poachers of rare collectable plants such as Pseudohydrosme, and timber extraction would open up the canopy and remove the intact habitat in which Pseudohydrosme grows. Additionally, slash and burn agriculture often follows logging trails and would negatively impact the populations of this species. Fortunately the logging concession was suspended due to representations to the President of Cameroon on the global importance of the biodiversity of Ebo (https://www.businesswire.com/news/home/20200817005135/en/Relief-in-the-ForestCameroonian-Government-Backtracks-on-the-Ebo-Forest accessed 19 Sept. 2020). However, the forest habitat of this species remains unprotected and threats of logging and conversion of the habitat to plantations remain. Pseudohydrosme ebo is therefore here assessed, on the basis of the range size given and threats stated as CR B1+2ab(iii), that is Critically Endangered.

Additional specimens: Cameroon, Littoral Region, Ebo proposed National Park, fl. 8 Oct. 2015 van der Burgt 1888 (K! YA!); ibid., st. (leaves) 9 Dec. 2019 (K!, MO!, P!, WAG!, YA!).

Phenology: flowering in September and early October; leaves early December; fruiting unknown.

Etymology: named as a noun in apposition for the forest of Ebo, in Cameroon's Littoral Region, Yabassi-Yingui Prefecture, to which this spectacular species is globally restricted on current evidence.

Local names and uses: none are known.

Notes: Pseudohydrosme ebo came to the attention of the first author in late Aug. 2018 on seeing van der Burgt 1888, collected in 2015. Plans were made to revisit the collection site at the next available opportunity, in December 2019, when leaves were found by the third author (van der Burgt 2377), but unfortunately fruits were not found. At the same time a second site was discovered $1.3 \mathrm{~km}$ distant from the site found in 2015. In February 2020 van der Burgt found at Kew an overlooked, additional specimen, Morgan 25, which is the earliest known record of the species, dating from 2010, and since it has multiple duplicates, has been selected as type of the new species. The associated collection data previously mislaid was rediscovered in May 2020.

Alvarez with van der Burgt, and Ngansop, discovered in Dec. 2019 seedlings of the new species, at three different stages, preserved as van der Burgt 2377 sheet 1/4 (see Fig 7). Clearly the species at this site is reproducing itself. Associated photographs also show plants of different ages.

Abwe \& Morgan, (2008) and Cheek et al. (2018a) characterise the Ebo forest, and give overviews of habitats, species and importance for conservation. Fifty-two globally threatened plant species are currently listed from Ebo on the IUCN Red List website and the number is set to rise rapidly. The discovery of a new species to science at the Ebo forest is not unusual. Since 
791

792

793

794

795

796

797

798

799

800

801

802

803

804

805

806

807

808

809

810

811

812

813

814

815

816

817

818

819

820

821

822

823

824

825

826

827

828

829

830

831

832

\section{Discussion}

834 The description of Pseudohydrosme ebo (this paper) necessitates the modification of the

835 circumscription of Pseudohydrosme in two respects. Firstly, in P. ebo the flower-bearing male

numerous new species have been published from Ebo in recent years. Examples of other species that, like Pseudohydrosme ebo appear to be strictly endemic to Ebo on current evidence are: Ardisia ebo Cheek (Cheek \& Xanthos, 2012), Crateranthus cameroonensis Cheek \& Prance (Prance \& Jongkind, 2015), Gilbertiodendron ebo Burgt \& Mackinder (Burgt et al., 2015), Inversodicraea ebo Cheek (Cheek et al., 2017), Kupeantha ebo M.Alvarez \& Cheek (Cheek et al., 2018b), Palisota ebo Cheek (Cheek et al., 2018a).

Further species described from Ebo have also been found further west, in the Cameroon Highlands, particularly at Mt Kupe and the Bakossi Mts (Cheek et al., 2004). Examples are Myrianthus fosi Cheek (Cheek \& Osborne, 2010), Salacia nigra Cheek (Gosline \& Cheek, 2014), Talbotiella ebo Mackinder \& Wieringa (Mackinder et al., 2010)

Additionally, several species formerly thought endemic to Mt Kupe have subsequently been found at Ebo, e.g. Coffea montekupensis Stoff. (Stoffelen et al., 1997), Costus kupensis Maas \& H. Maas (Maas-van der Kamer et al., 2016), Microcos magnifica Cheek (Cheek, 2017), and Uvariopsis submontana Kenfack, Gosline \& Gereau (Kenfack et al., 2003).

Therefore, it is possible that Pseudohydrosme ebo might yet also be found in the Cameroon highlands, e.g. at Mt Kupe, further extending westward the known range of the genus. However, this is thought to be only a relatively small possibility given the spectacular nature of this plant, and the high level of survey effort at e.g. Mt Kupe: if it occurred there it is highly likely that it would have been recorded already.

Additional characters separating Pseudohydrosme ebo from P. gabunensis are show in table 1.

It is to be hoped that further studies of live plants of $P$. ebo will be possible to determine if, like $P$. gabunensis it also reproduces asexually from the root tips.

The biogeography of the Cameroonian Pseudohydrosme ebo is very different from that of the two Gabonese species of the genus growing c. $450 \mathrm{~km}$ to the South. The Gabonese species grow on recently deposited, sandy coastal soils. Although the Gabonese species also experience a wet season of about 3 metres of rainfall per annum, it is differently distributed: the dry season in Libreville occurs from June to September inclusive and is colder than the wet season. In contrast at Ebo the geology at the Pseudohydrosme location is ancient, highly weathered basement complex, with some ferralitic areas in foothill areas which are inland, c. $100 \mathrm{~km}$ from the coast. The wet season (successive months with cumulative rainfall $>100 \mathrm{~mm}$ ) is almost the inverse of at Libreville, falling between March and November and is colder than the dry season (Abwe \& Morgan 2008). In addition, the affinities of Ebo as indicated by shared plant species, seems to be with other parts of the Cross-Sanaga biogeographic area, the Cameroon Highlands, rather than with Gabon (see above).

Peer] reviewing PDF | (2020:10:53447:1:1:CHECK 2 Dec 2020) 
836 and female portions of the inflorescence are not completely contiguous, the distal region of the

837 female zone shows naked parts of the axis and the female flowers are laxly arranged throughout, 838 while in the other species of Pseudohydrosme there is no naked portion and the spadix axis is

839

840

841

842

843

844

845

846

847

848

849

850

851

852

853

854

855

856

857

858

859

860

861

862

863

864

865

866

867

868

869

870

871

872

873

874

875

876

877

878

879

880

881 completely covered in flowers. Thirdly the trilocular ovaries normal in Pseudohydrosme ebo are different to those of the other two species which are usually bilocular, and only very rarely otherwise.

Although indicated as potentially congeneric with Anchomanes by Hetterscheid \& Bogner (2013) who cited only the difference in ovary locularity as a basis for maintaining the separation, in fact five other characters support maintaining the separation of these two genera (see table 2 below).Two of these characters were discovered for the first time by Hetterscheid \& Bogner (2013) . These are 1) the development in the fruit of a stipe and 2) reproducing asexually from the fleshy roots: producing new plants distant from the parent rhizome. The last character is specifically remarked to be definitively absent from Anchomanes species, which have been studied in detail in cultivation (Hetterscheid, \& Bogner 2013). However, Hay (in litt.) reports anecdotally, that Anchomanes can be propagated in cultivation by root cuttings.

However, there is no doubt that Anchomanes and Pseudohydrosme are closely related, sharing so many characters. Although the two genera have been stated to have "at least a sister group relationship" (Hetterscheid, \& Bogner 2013), as those authors pointed out, only one species of each genus was included in the molecular phylogenetic analysis upon which this statement was based (Cabrera et al., 2008). We speculate that the differences in inflorescence structure that help distinguish between the two genera (table 2), might be due to two different pollination syndromes being in play. That laticifers were not detected in Pseudohydrosme might have been due to insufficient material being available. Resampling might yet discover them. The difference in peduncle character state that currently separates the two genera are encompassed within one genus elsewhere in the family, with intermediates connecting the two states., e.g. in Amorphophallus. It cannot be ruled out therefore that one of these genera might be nested inside the other, in which case it might be necessary to sink Pseudohydrosme into Anchomanes. However further molecular analysis, sampling additional taxa of each genus, is advisable before any such action is needed. It is intended to address this in a future project.

\section{Conclusions}

The discovery of a new species of Pseudohydrosme in Cameroon, far from the border with Gabon, is completely unexpected after nearly 130 years in which no additional taxa have been added to the genus. It is also unexpected because one would not predict from the pre-existing 
882 data on the genus that such a new species would be so biogeographically and climatically

883 disjunct from its congeners in the Libreville area of Gabon (see under Pseudohydrosme ebo

884 above). However, examples of even more dramatically unexpected African range extensions

885 have occurred recently such as the westward extension by $2400 \mathrm{~km}$ of the genus Ternstroemia

886 Mutis ex L.f., of Talbotiella Baker by $1400 \mathrm{~km}$, and of the genus Metarungia Baden by 1200

$887 \mathrm{~km}$, or in the other direction, eastwards, $1500 \mathrm{~km}$ in Mischogyne Exell (Cheek et al. 2019; van

888 der Burgt et al. 2018; Darbyshire et al., 2008; Gosline et al.,2019 respectively). Such

889 discoveries underline how incomplete our knowledge of the geography of African plant genera

890 remains. They also underline the urgency for uncovering such taxa whileit is still possible since

891 in all but one of the cases given, the range extension resulted from finding a new species to

892 science with a narrow geographic range and/or very few individuals, and which face threats to

893 their natural habitat, putting these species at high risk of extinction. About 2000 new species of

894 vascular plants have been discovered each year for the last decade or more. Until species are

895 known to science, they cannot be assessed for their conservation status and the possibility of

896 protecting them is reduced (Cheek et al., 2020). Documented extinctions of plant species are

897 increasing, e.g. Oxygyne triandra Schltr. of Southwest Region, Cameroon is now known to be

898 globally extinct (Cheek et al., 2018c). In some cases species appear to be extinct even before

899 they are known to science, such as Vepris bali Cheek, also from the Cross-Sanaga interval in

900 Cameroon (Cheek et al., 2018d) and elsewhere, Nepenthes maximoides Cheek (King \& Cheek,

901 2020). Most of the $>800$ Cameroonian species in the Red Data Book for the plants of Cameroon

902 are threatened with extinction due to habitat clearance or degradation, especially of forest for

903 small-holder and plantation agriculture following logging (Onana \& Cheek, 2011). Efforts are

904 now being made to delimit the highest priority areas in Cameroon for plant conservation as

905 Tropical Important Plant Areas (TIPAs) using the revised IPA criteria set out in Darbyshire et al.

906 (2017). This is intended to help avoid the global extinction of additional endemic species such as

907 Pseudohydrosme ebo which will be included in the proposed Ebo Forest IPA.

908

909 Acknowledgements

910 Ekwoge Abwe and Bethan Morgan of San Diego Zoo Global and their team at the Ebo Forest

911 Research Project are thanked hugely for expediting our botanical surveys in the Ebo forest of

912 Cameroon over several years. In particular Bethan Morgan is acknowledged for collecting the

913 type specimens of Pseudohydrosme ebo.

914 Janis Shillito is thanked for typing the manuscript. The heads of IRAD (Institute of Research in

915 Agronomic Development)-National Herbarium of Cameroon, Yaoundé, successively Jean-

916 Michel Onana, Florence Ngo Ngwe and Eric Nana, are thanked for arranging permits and co-

917 ordinating the co-operation with the Royal Botanic Gardens, Kew. The late Josef Bogner is

918 thanked for conversations on Araceae. Maria Alvarez is thanked for photos of seedlings of

919 Pseudohydrosme ebo. Marcello Sellaro of the Tropical Nursery, Royal Botanic Gardens, Kew, is

920 thanked for cultivation of and facilitating access to live material of Araceae. David Prehsler,

921 University of Vienna Botanic Garden is thanked for the photo of Pseudohydrosme gabunensis

922 and for notes on the scent of that plant. Alistair Hay, Simon Mayo and another, anonymous

923 reviewer, are all thanked for their detailed, expert and painstaking reviews of an earlier version

924 of this paper, which have greatly improved the final version.

925

926

927

\section{REFERENCES}


928

929

930

931

932

933

934

935

936

937

938

939

940

941

942

943

944

945

946

947

948

949

950

951

952

953

954

955

956

957

958

959

960

961

962

963

964

965

966

967

968

969

970

971

972

Abwe EE, Morgan BJ. 2008. The Ebo Forest: four years of preliminary research and conservation of the Nigeria-Cameroon chimpanzee (Pan troglodytes vellerosus). Pan Africa News 15: 26-29. https://doi.org/10.5134/143494

Amshoff GJH. 1958. Notes on Myrtaceae VII. Myrtaceae of French Equatorial Africa. Acta Botanica Neerlandica 7: 53-58. doi:10.1111/j.1438-8677.1958.tb00605.x

Anon. 1901. A List of the Collectors Whose Plants Are in the Herbarium of the Royal Botanic Gardens, Kew, to 31st December, 1899. Bulletin of Miscellaneous Information (Royal Botanic Gardens, Kew) 169/171: 1-80. https://doi:10.2307/4113200

Bachman S, Moat J, Hill AW, de la Torre J, Scott B. 2011. Supporting Red List threat assessments with GeoCAT: geospatial conservation assessment tool, in: Smith V, Penev, eds. eInfrastructures for data publishing in biodiversity science. ZooKeys 150: 117-126. Available from: http://geocat.kew.org/ [accessed 19 July 2020].

Barthlott W, Lauer W, Placke A. 1996. Global distribution of species diversity in vascular plants: towards a world map of phytodiversity. Erkunde 50: 317-328 (with supplement and figure).

Bogner J. 1981. Pseudohydrosme gabunensis Engl. Aroideana 4(1): 31-37.

Bogner J, Petersen G. 2007. The chromosome numbers of the aroid genera. Aroideana 30: 8290 .

Cable S, Cheek M. 1998. The plants of Mt Cameroon, a conservation checklist. Kew: Royal Botanic Gardens.

Cabrera LI, Salazar GA, Chase MW, Mayo SJ, Bogner J, Dávila P. 2008. Phylogenetic relationships of aroids and duckweeds (Araceae) inferred from coding and noncoding plastid DNA. American Journal of Botany 95(9):1153-1165. doi:10.3732/ajb.0800073

Cheek M. 1992. Botanical Survey of the Proposed Mabeta-Moliwe Forest Reserve in SW Cameroon: Report on Limbe Gardens Conservation Project. Kew: Royal Botanic Gardens.

Cheek M. 2017. Microcos magnifica (Sparrmanniaceae) a new species of cloudforest tree from Cameroon. PeerJ 5:e4137 https://doi.org/10.7717/peerj.4137

Cheek M, Cable S. 1997. Plant Inventory for conservation management: the Kew-Earthwatch programme in Western Cameroon, 1993-96, pp. 29-38 in Doolan, S. (Ed.) African Rainforests and the Conservation of Biodiversity, Oxford: Earthwatch Europe.

Cheek M, Osborne J. 2010. Myrianthus fosi (Cecropiaceae) a new submontane fruit tree from Cameroon. In: Harvey Y.H., Tchiengue B. \& Cheek M. 2010. The plants of the Lebialem Highlands, a conservation checklist: 59-64. Kew: Royal Botanic Gardens.

Peer] reviewing PDF | (2020:10:53447:1:1:CHECK 2 Dec 2020) 
973

974

975

976

977

978

979

980

981

982

983

984

985

986

987

988

989

990

991

992

993

994

995

996

997

998

999

1000

1001

1002

1003

1004

1005

1006

1007

1008

1009

1010

1011

1012

1013

1014

1015

Cheek M, Xanthos M. 2012. Ardisia ebo sp. nov. (Myrsinaceae) a creeping forest subshrub of Cameroon and Gabon. Kew Bulletin 67: 281-284. https://doi.org/10.1007/s12225-012-9362-8

Cheek M, Alvarez-Agiurre MG, Grall A, Sonké B, Howes M-JR, Larridon L. 2018b.

Kupeantha (Coffeeae, Rubiaceae), a new genus from Cameroon and Equatorial Guinea. PLoS ONE 13: 20199324. https://doi.org/10.1371/journal.pone.0199324

Cheek, M, S Cable, FN Hepper, N Ndam \& J Watts. 1996. Mapping plant biodiversity on Mt. Cameroon. pp. 110-120 in van der Maesen, van der Burgt \& van Medenbach de Rooy (Eds), The Biodiversity of African Plants (Proceedings XIV AETFAT Congress). Kluwer.

Cheek M, Feika A, Lebbie A, Goyder D, Tchiengue B, Sene O, Tchouto P, van der Burgt X. 2017. A synoptic revision of Inversodicraea (Podostemaceae). Blumea 62: 125-156.

https://doi.org/10.3767/blumea.2017.62.02.07

Cheek M, Gosline G, Onana J-M. 2018d. Vepris bali (Rutaceae), a new critically endangered (possibly extinct) cloud forest tree species from Bali Ngemba, Cameroon. Willdenowia 48: 285 292. doi: https://doi.org/10.3372/wi.48.48207

Cheek M, Haba PM, Konomou G, van der Burgt' XM. 2019. Ternstroemia guineensis (Ternstroemiaceae), a new endangered, submontane shrub with neotropical affinities, from Kounounkan, Guinea, W. Africa. Willdenowia 49(3): 351-360.

https://doi.org/10.3372/wi.49.49306

Cheek M, Harvey Y, Onana JM. 2010. The plants of Dom, Bamenda Highlands, Cameroon, A Conservation Checklist, RBG, Kew, 162pp.

Cheek M, Harvey Y, Onana J-M. 2011. The Plants of Mefou Proposed National Park, Yaoundé, Cameroon, A Conservation Checklist. Kew: Royal Botanic Gardens.

Cheek M, Mackinder B Gosline G, Onana J, Achoundong G. 2001. The phytogeography and flora of western Cameroon and the Cross River-Sanaga River interval. Systematics and Geography of Plants 71: 1097-1100. https://doi.org/10.2307/3668742

Cheek M, Nic Lughadha E, Kirk P, Lindon H, Carretero J, Looney B, Douglas B, Haelewaters D, Gaya E, Llewellyn T, Ainsworth M, Gafforov Y, Hyde K, Crous P, Hughes M, Walker BE, Forzza RC, Wong KM, Niskanen T. 2020. New scientific discoveries: plants and fungi. Plants, People Planet 2:371-388.

https://doi.org/10.1002/ppp3.10148

Cheek M, Onana J-M, Pollard BJ. 2000. The Plants of Mount Oku and the Ijim Ridge, Cameroon, a Conservation Checklist. Kew: Royal Botanic Gardens, 220 pp.

Peer] reviewing PDF | (2020:10:53447:1:1:CHECK 2 Dec 2020) 
1016 Cheek M, Pollard BJ, Darbyshire I, Onana J, Wild C. 2004. The plants of Kupe,

1017 Mwanenguba and the Bakossi Mountains, Cameroon. A conservation checklist. Kew: Royal

1018 Botanic Gardens.

1019

1020

Cheek M, Prenner G, Tchiengué B, Faden RB. 2018a. Notes on the endemic plant species of

1021 the Ebo Forest, Cameroon, and the new, Critically Endangered, Palisota ebo (Commelinaceae).

1022 Plant Ecology and Evolution 151(3): 434-441. https://doi.org/10.5091/plecevo.2018.1503

1023

1024

Cheek M, Tsukaya H, Rudall PJ, Suetsugu K. 2018c. Taxonomic monograph

1025 of Oxygyne (Thismiaceae), rare achlorophyllous mycoheterotrophs with strongly disjunct

1026

1027

1028 distribution. PeerJ 6:e4828https://doi.org/10.7717/peerj.4828

\section{Cusimano N, Bogner J, Mayo SJ, Boyce PC, Wong SY, Hesse M, Hetterscheid WLA,}

1029

Keating RC, French JC. 2011. Relationships within the Araceae: comparison of morphological

1030 patterns with molecular phylogenies. American Journal of Botany 98(4): 1-15.

1032

1033

Darbyshire I, Anderson S, Asatryan A, Byfield A, Cheek M, Clubbe C, Ghrabi Z, Harris T, Heatubun CD, Kalema J, Magassouba S, McCarthy B, Milliken W, Montmollin B de, Nic Lughadha E, Onana JM, Saidou D, Sarbu A, Shrestha K \& Radford, EA. 2017. Important Plant Areas: revised selection criteria for a global approach to plant conservation. Biodiversity Conservation 26: 1767-1800. https://doi.org/10.1007/s10531-017-1336-6.

Darbyshire I, Vollesen K, Chapman HM. 2008. A remarkable range disjunction recorded in Metarungia pubinervia (Acanthaceae). Kew Bulletin. 63(4):613-5.

Engler A. 1892. Araceae Africanae I. Botanischr Jahrbücher für Systematik, Pflanzengeschichte und Pflanzengeographie 15: 447-466.

Engler A. 1911. Pseudohydrosme in: Engler A. Das Pflanzenreich IV 23C(Araceae-Lasioideae): 47-49. Leipzig.

Engler A, Prantl K. 1897. Die natürlichen Pflanzenfamilien nebst ihren Gattungen und wichtigeren Arten: Ergänzungsheft enthaltend die Nachträge zu den Teilen II-IV. W. Engelmann.

1051

1052

Gosline G, Malecot V. 2011. A monograph of Octoknema (Octoknemataceae-Olacaceae s.l.). Kew Bulletin 66(3): 367-404. https://doi.org/10.1007/s12225-011-9293-9

Gosline G, Cheek M, Kami T. 2014. Two new African species of Salacia (Salacioideae, 1057 Celastraceae). Blumea 59: 26-32. https://doi.org/10.3767/000651914x682026 9804-7 
1062 Harvey Y, Pollard BJ, Darbyshire I, Onana J, Cheek M. 2004. The plants of Bali Ngemba

1063 Forest Reserve, Cameroon. a conservation checklist. Kew: Royal Botanic Gardens.

1064

1065

Harvey YH, Tchiengue B, Cheek M. 2010. The plants of the Lebialem Highlands, a

1066

1067

1068

1069

1070

1071

1072

1073

1074

1075

1076

1077

1078

1079

1080

1081

1082

1083

1084

1085

1086

1087

1088

1089

1090

1091

1092

1093

1094

1095

1096

1097

1098

1099

Hay A. 2019. Durianology, discovery, and saltation - the evolution of aroids. Gardens 'Bulletin Singapore 71(Suppl. 2): 259-316.

Hay A, Bogner J, Boyce PC. 1994. Nephthytis Schott (Araceae) in Borneo. A new species and a new generic record for Malesia. Novon 4: 365-368. https://doi.org/10.2307/3391445

Hetterscheid W, Bogner J. 2013. Recent observations and cultivation of Pseudohydrosme gabunensis Engl. (Araceae). Aroideana 36: 104-113.

Huynh KL. 1986. Pandanaceae. Flore du Gabon. 28: 3-22.

IPNI. 2020. International Plant Names Index. The Royal Botanic Gardens, Kew, Harvard University \& Libraries and Australian National Botanic Gardens. Available at http://www.ipni.org (accessed 05 June 2020).

IUCN. 2012. IUCN Red List Categories and Criteria: Version 3.1. Second edition. Gland, Switzerland and Cambridge, UK: IUCN. Available at http://www.iucnredlist.org/ (accessed: 07/2020).

Jacques-Félix H. 1986. Description d'un Tristemma (Melastomataceae) nouveau du Gabon. Bulletin du Muséum national d'Histoire naturelle de Paris, 4e série, section B, Adansonia 8:191-193.

JStor Global Plants. 2020. continuously updated) Available at http://plants.jstor.org/ (accessed 14 June 2020).

Keating RC. 2002. Acoraceae and Araceae. In M. Gregory and D.F. Cutler [eds.], Anatomy of the monocotyledons, vol. 9. Oxford: University Press, Oxford, U.K.

Kenfack D, Gosline G, Gereau, RE, Schatz G. 2003. The genus Uvariopsis in Tropical Africa, with a recombination and one new species from Cameroon. Novon 13: 443-449.

https://doi.org/10.2307/3393377

1100 King C, Cheek M. 2020. Nepenthes maximoides (Nepenthaceae) a new, critically endangered 1101 (possibly extinct) species in Sect. Alatae from Luzon, Philippines showing striking pitcher 1102 convergence with $N$. maxima (Sect. Regiae) of

1103 Indonesia. PeerJ 8: 9899 https://doi.org/10.7717/peerj.9899

1104 Lachenaud O, Stévart T, Ikabanga D, Ngagnia Ndjabouda E, Walters G. 2013. Les forêts 1105 littorales de la région de Libreville (Gabon) et leur importance pour la conservation: description 
1106 d'un nouveau Psychotria (Rubiaceae) endémique. Plant Ecology and Evolution 146(1):68-74.

1107 https://doi.org/10.5091/plecevo.2013.744

1108

1109

1110

Lovell R, Cheek M. 2020 (in press). Pseudohydrosme gabunensis. The IUCN Red List of Threatened Species 2020.

1111 Maas-van de Kamer H, Maas PJM, Wieringa JJ, Specht CD. 2016. Monograph of African

1112 Costus. Blumea - Biodiversity, Evolution and Biogeography of Plants 61: 280-318.

1113 https://doi.org/10.3767/000651916X694445

1114 Mackinder BA, Wieringa JJ, van der Burgt XM. 2010. A revision of the

1115 genus Talbotiella Baker f. (Caesalpinioideae: Leguminosae). Kew Bulletin 65: 401-420.

1116 https://doi.org/10.1007/s12225-010-9217-0

1117

1118

1119

1120

1121

1122

1123

1124

1125

1126

1127

1128

1129

1130

1131

1132

1133

1134

Mayo SJ, Bogner J, Boyce PC. 1997. The Genera of Araceae. Royal Botanic Gardens, Kew.

Nauheimer LD, Metzler, Renner SS. 2012. Global history of the ancient monocot family Araceae inferred with models accounting for past continental positions and previous ranges based on fossils. New Phytologist.195(4): 938-950.

Omino E. 1996. A contribution to the leaf anatomy and taxonomy of Apocynaceae in Africa: the leaf anatomy of Apocynaceae in East Africa; a monograph of Pleiocarpinae (series of revisions of Apocynaceae 41). Wageningen Agricultural University Papers. 96(1): 1-178.

Onana J, Cheek M. 2011. Red Data Book of the flowering plants of Cameroon, IUCN global assessments. Kew: Royal Botanic Gardens.

Prance GT, Jongkind CCH. 2015. A revision of African Lecythidaceae. Kew Bulletin 70: 6: 13. https://doi.org/10.1007/s12225-014-9547-4

1135

Ruhsam M, Govaerts R, Davis AP. 2008. Nomenclatural changes in preparation for a World 1136 Rubiaceae Checklist. Botanical Journal of the Linnean Society. 157(1):115-24.

1138

Stoffelen P, Cheek M, Bridson D, Robbrecht E. 1997. A new species of Coffea (Rubiaceae)

1139

1140

1141 and notes on Mt Kupe (Cameroon). Kew Bulletin 52: 989-994. https://doi.org/10.2307/3668527

1142 National, 666-948.

1143 Sosef MSM, Wieringa JJ, Jongkind CCH, Achoundong G, Azizet Issembé Y, Bedigian D, 1144 Van Den Berg RG, Breteler FJ, Cheek M, Degreef J. 2005. Checklist of Gabonese Vascular 1145 Plants. Scripta Botanica Belgica 35. National Botanic Garden of Belgium.

1146 Taton A. 1979. Contribution à l'étude du genre Ardisia Sw. (Myrsinaceae) en Afrique tropicale. 1147 Bulletin Du Jardin Botanique National De Belgique / Bulletin Van De National Plantentuin Van 1148 België, 49: 81-120. doi:10.2307/3667819 
1149 Thiers B. 2020. continuously updated. Index Herbariorum: A global directory of public herbaria 1150 and associated staff. New York Botanical Garden's Virtual Herbarium. Available at

1151 http://sweetgum.nybg.org/ih/ (accessed June 2020).

1152

1153

Thistleton-Dyer. 1901. Flora of Tropical Africa 8. London: Lovell Reeve \& Co.

1154

1155

1156

1157

Tillich HJ. 2014. A New Look at Seedlings of Araceae. Aroideana 37:1-14

1158

van der Burgt XM, Mackinder BA, Wieringa JJ, de la Estrella M. 2015.

1159

The Gilbertiodendron ogoouense species complex (Leguminosae: Caesalpinioideae), Central

1160

1161 Africa. Kew Bulletin 70: 29. https://doi.org/10.1007/s12225-015-9579-4

1162

van der Burgt XM, Molmou D, Diallo A, Konomou G, Haba PM, Magassouba S.

1163

2018. Talbotiella cheekii (Leguminosae: Detarioideae), a new tree species from Guinea. Kew

1164

1165

Bulletin 73, 26 https://doi.org/10.1007/s12225-018-9755-4

Van HT, Nguyen-Phi N, Luu HT. 2020. The Phylogenetic position of Aglaodorum Schott

1167

(Araceae-Aglaonemateae). Thaiszia Journal of Botany, Ko šice 30 (1): 93-101.

1168

https://doi.org/10.33542/TJB2020-1-07

1170

Walters G, Ndjabounda EN, Ikabanga D, Biteau JP, Hymas O, White LJ, Obiang AM,

1171

Ondo PN, Jeffery KJ, Lachenaud O, Stevart T. 2016. Peri-urban conservation in the Mondah

1172 forest of Libreville, Gabon: Red List assessments of endemic plant species, and avoiding

1173 protected area downsizing. Oryx 50(3):419-30. https://doi.org/10.1017/s0030605315000204 
Figure 1

Pseudohydrosme ebo (van der Burgt 1888, K, YA).

Photo of flowering, leafless plant at Ebo forest, Oct. 2015. Photo by Xander van der Burgt.

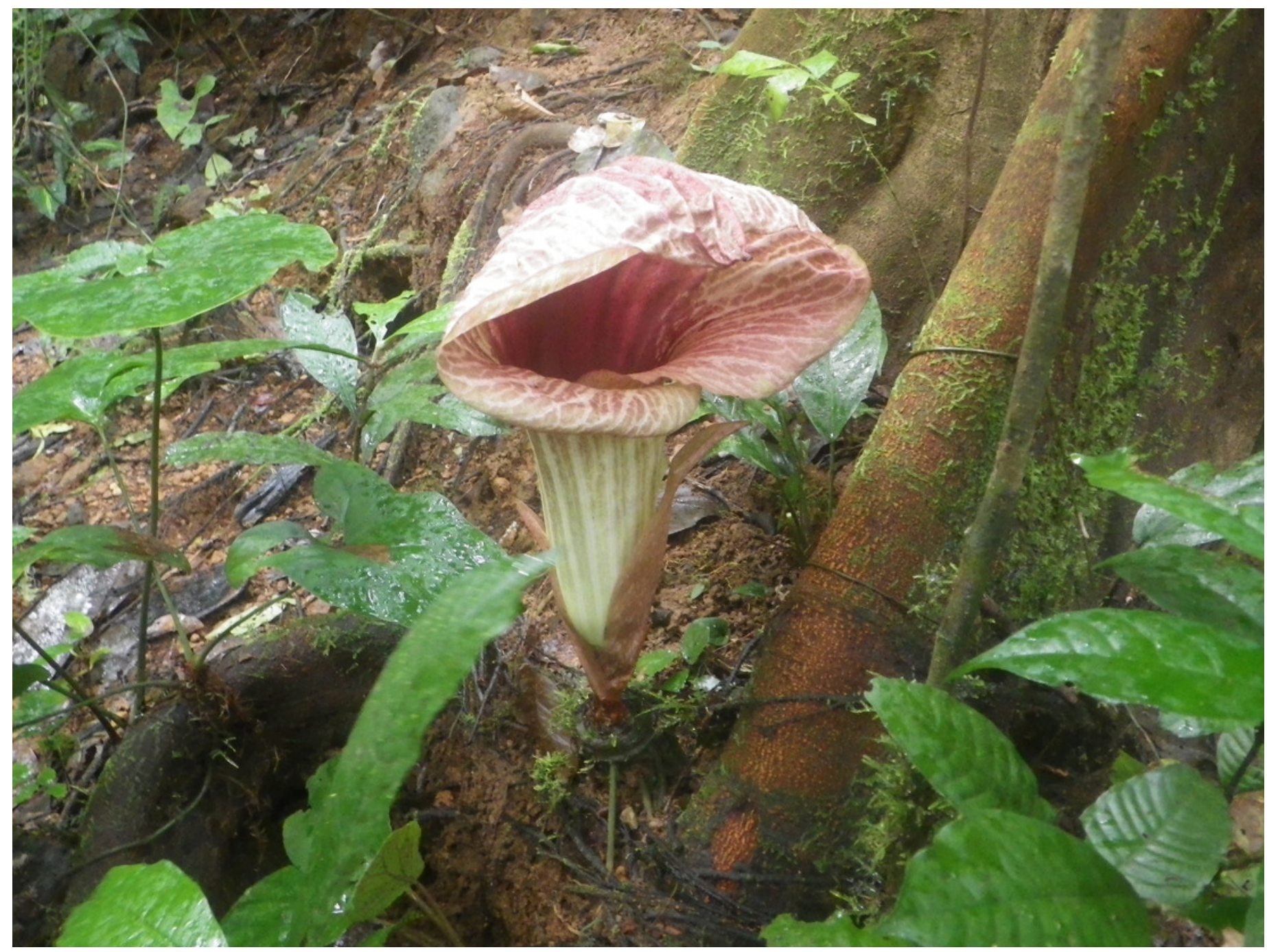


Figure 2

Pseudohydrosme ebo (van der Burgt 2377, K, YA).

Photo of plant in leaf, in habitat, Ebo forest, December, March 2019. Photo by Xander van der Burgt.

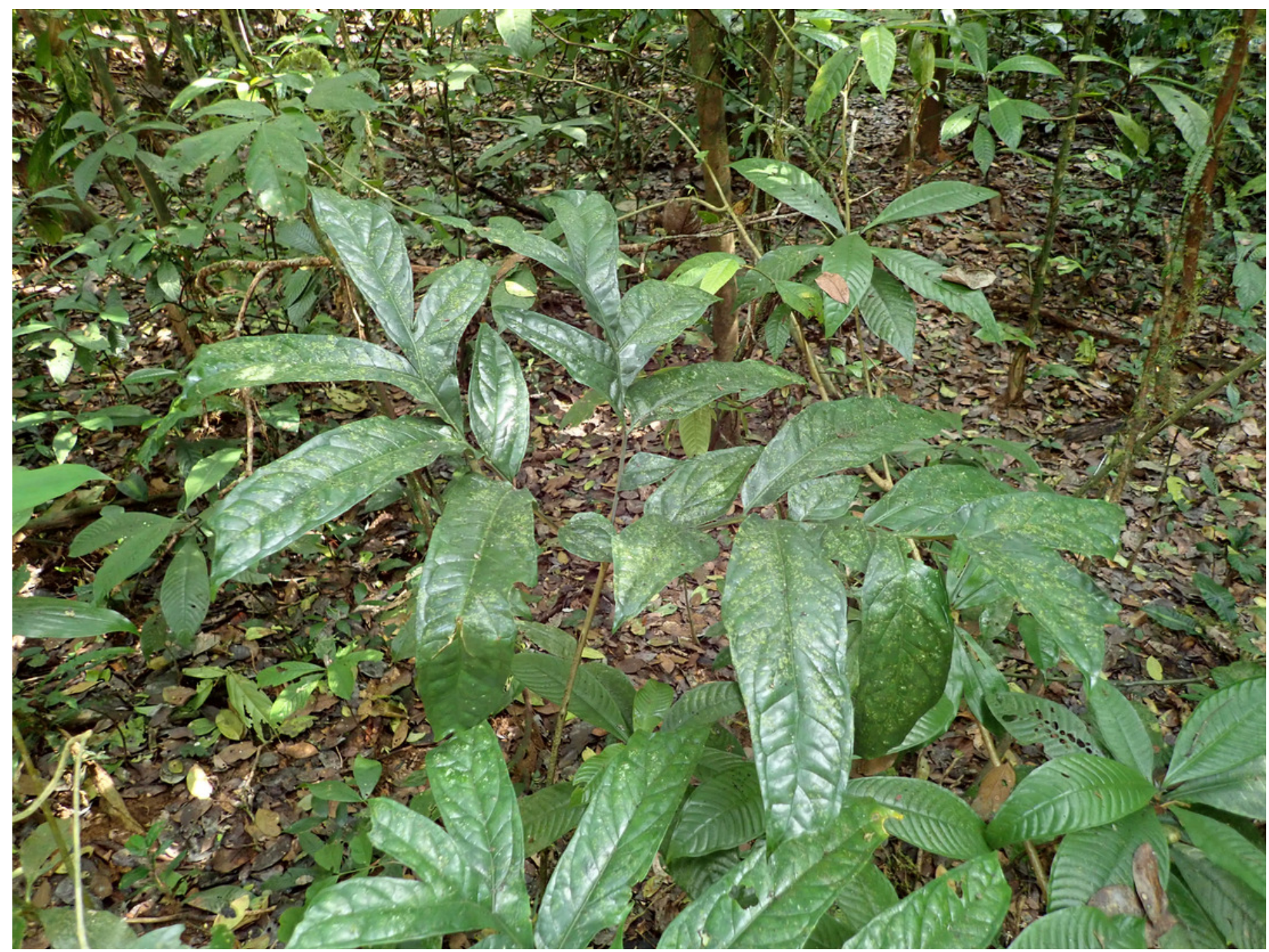


Figure 3

Global distribution of the species of the African genus Pseudohydrosme

Red dot $=P$. buettneri; black dots $=P$.gabunensis (location not available for Congo specimen); blue dot $=P$. ebo.

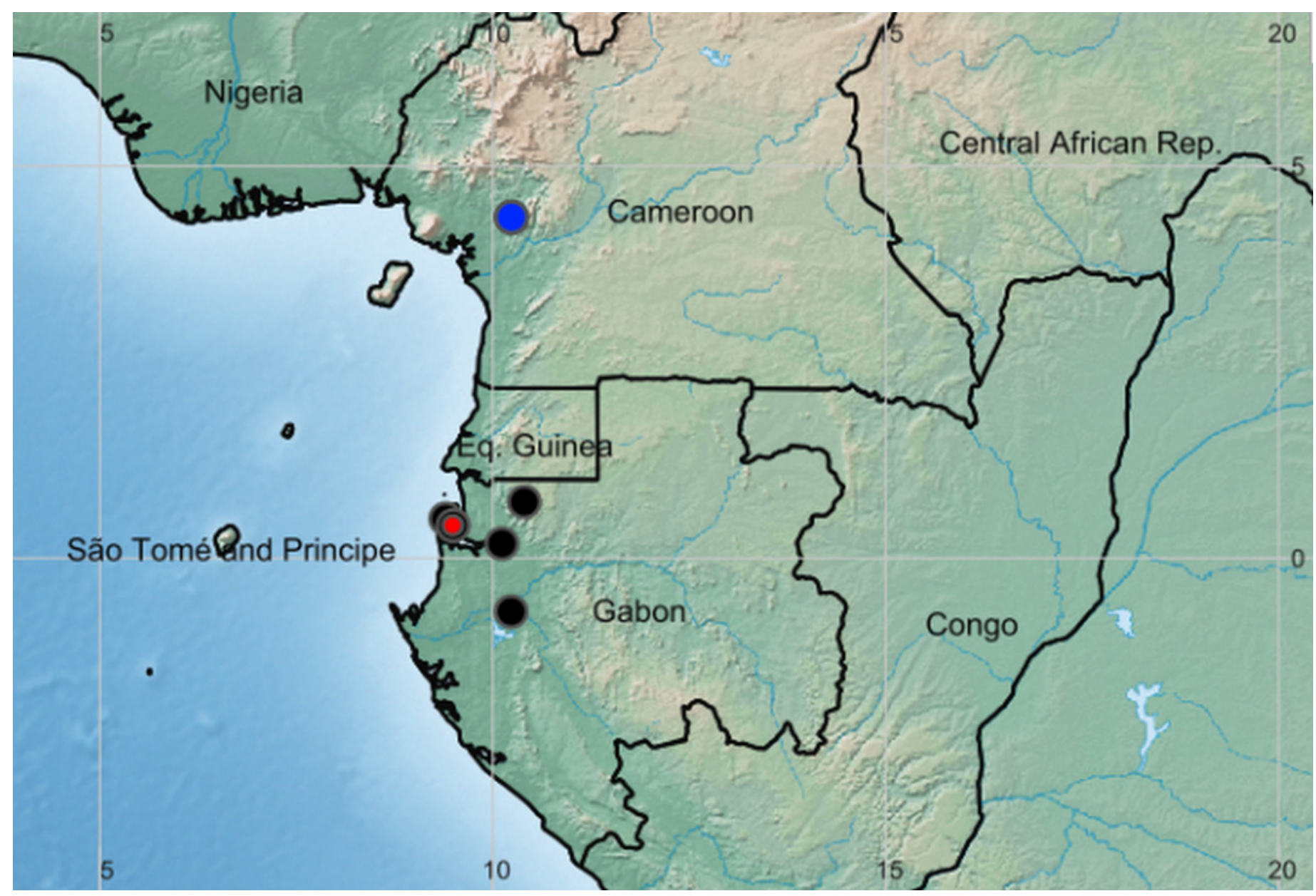




\section{Figure 4}

Pseudohydrosme buettneri (Buettner 519, B).

Drawing of flowering plant. (A) habit, rhizome and inflorescences; (B) spadix after removal of spathe showing from base to apex, female, male and staminodal flowers; ( $C \& D)$ paired stamens, side view; $(E)$ paired stamens flowers, transverse section; $(F \& G)$ staminodes, sterile male flower; $(\mathrm{H})$ female flower, entire, side view; $(\mathrm{J})$ female flower, longitudinal section. Reproduced from protologue, (Engler, 1892: taf. XVII). Drawn by Josef Pohl. 


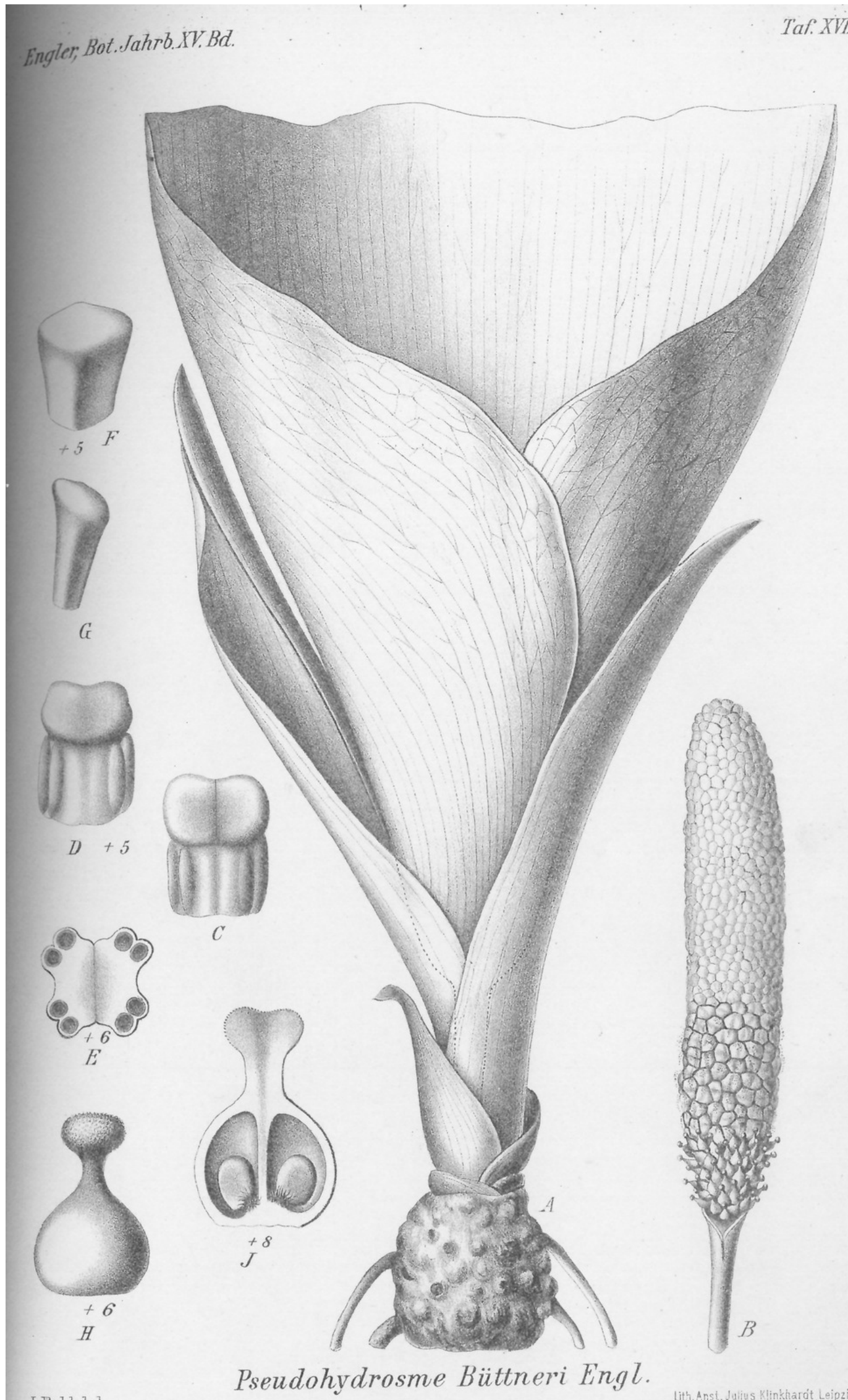

J.Pohk del.

Verlag v. Wilh.Engelmann Lipzig. 
Figure 5

Pseudohydrosme gabunensis

Photo of flowering, leafless plant cultivated at University of Vienna Botanic Garden (courtesy of David Prehsler). 


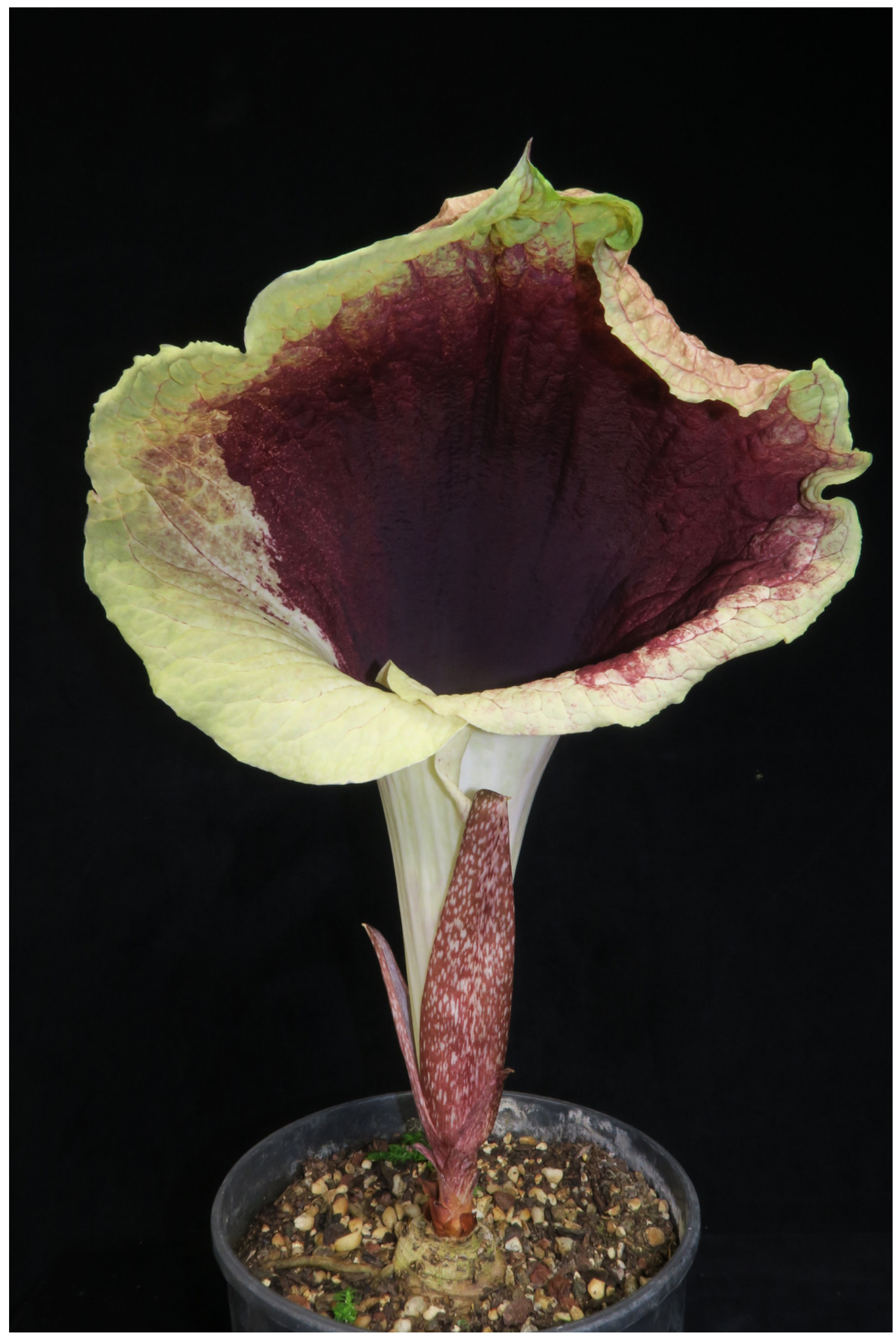

Peer) reviewing PDF | (2020:10:53447:1:1:CHECK 2 Dec 2020) 


\section{Figure 6}

Pseudohydrosme ebo (van der Burgt 1888, K, YA).

Drawing of flowering plant. (A ventral side view \& B oblique side view) habit, rhizome and inflorescences; (C) inflorescence, longitudinal section, showing spadix from base to apex with sparse female flowers, partially naked axis of female zone, separated by naked axis from the densely flowered, male zone; (D) group of three stamens, ventral side view; (E) stamen; (F) stamen, transverse section; $(G)$ female flower, entire, side view; $(H)$ female flower, longitudinal section; (I) ovary, transverse section. Drawn by Andrew Brown. 


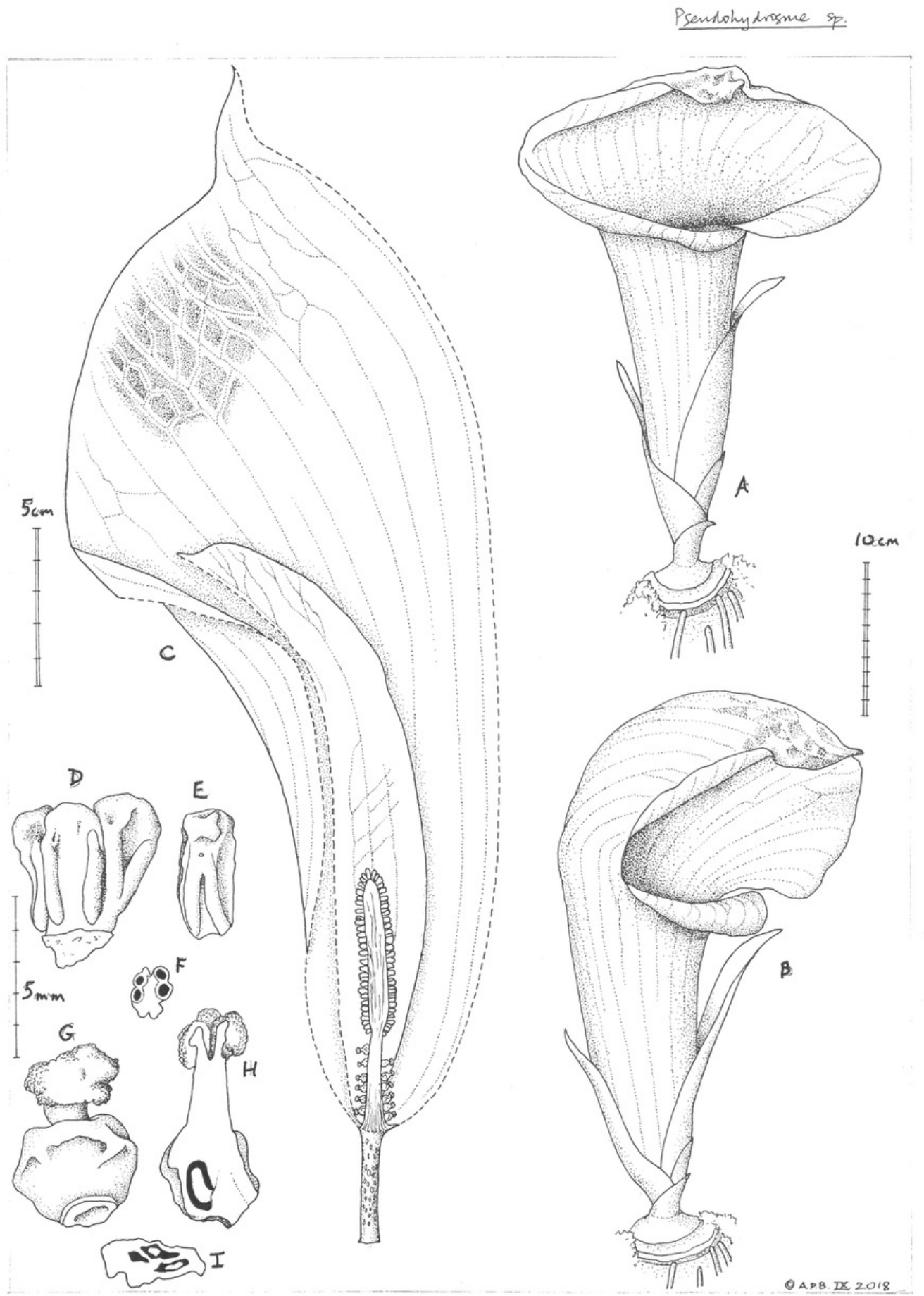

Psendolydroome sp. del. Anshew Brows Siptember 2018 


\section{Figure 7}

Pseudohydrosme ebo (A-D from van der Burgt 2377, K, YA; E from Morgan 25, K,YA).

(A) primary lateral division (one of three divisions) of leaf-blade, with petiole folded, behind;

(B) seedling (probably in first year); (C) seedling plant (probably in third or later year); (D)

seedling leaf-blade (pre-mature); (E obique view (B) \& F from above); trilobed stigma. Drawn by Andrew Brown. 


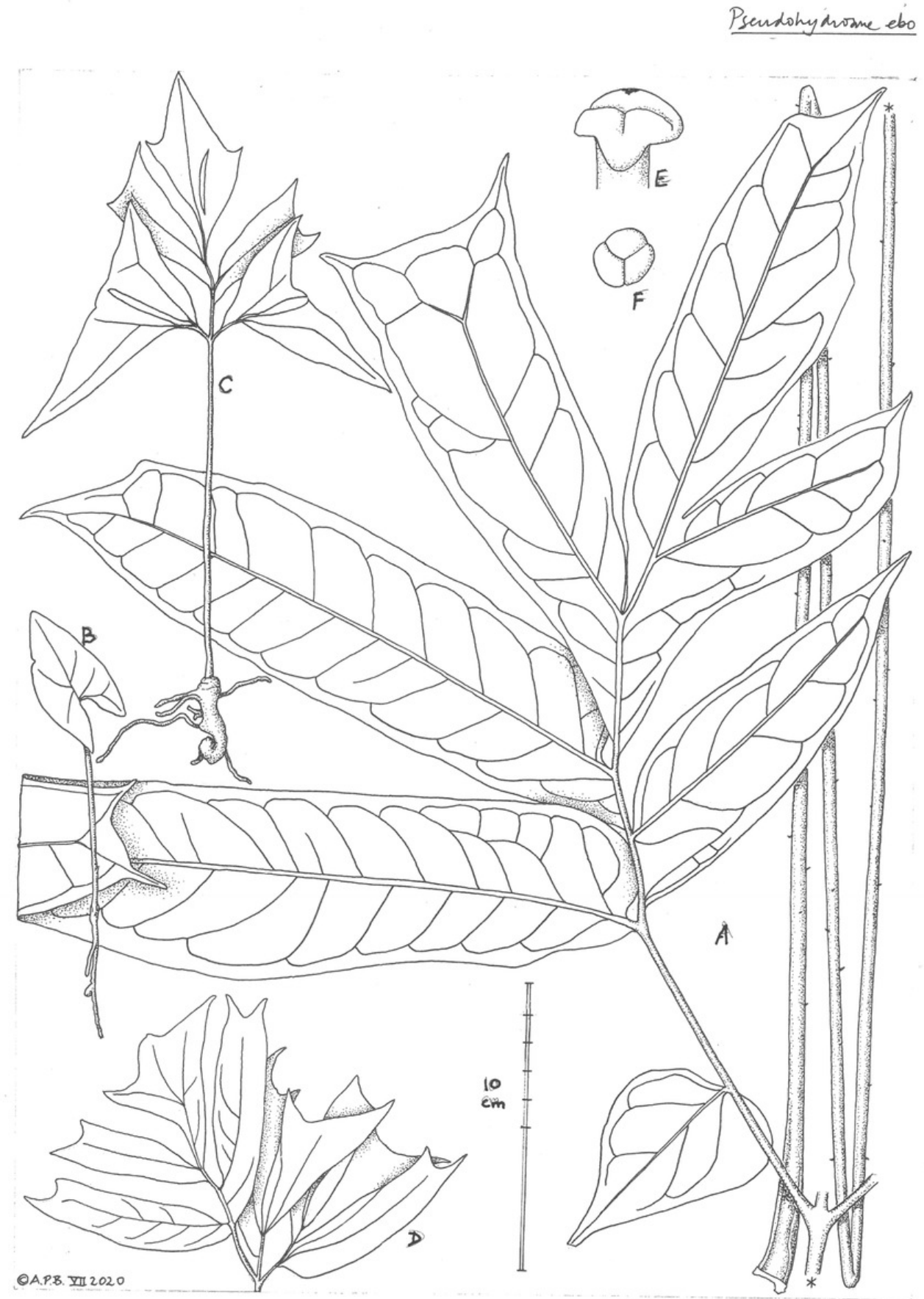

Psendshydroime ebo del. Andrew Brown July 2020 


\section{Table $\mathbf{1}$ (on next page)}

Characters separating Pseudohydrosme gabunensis from Pseudohydrosme ebo

Data for Pseudohydrosme gabunensis from Bogner (1981:33), Hetterscheid \& Bogner (2014:104-113), and live material cultivated at Royal Botanic Gardens, Kew. 
2 Table 1:

3 Characters separating Pseudohydrosme gabunensis from Pseudohydrosme ebo.

4

5 Data for Pseudohydrosme gabunensis from Bogner (1981:33), Hetterscheid \& Bogner

6 (2013:104-113), Hay (in litt.), and live material cultivated at Royal Botanic Gardens, Kew.

7 Data for Pseudohydrosme buettneri from Engler (1892). Data for Pseudohydrosme ebo: this

8 paper.

\begin{tabular}{|c|c|c|c|}
\hline & $\begin{array}{l}\text { Pseudohydrosme } \\
\text { gabunensis }\end{array}$ & Pseudohydrosme ebo & $\begin{array}{l}\text { Pseudohydrosme } \\
\text { buettneri }\end{array}$ \\
\hline $\begin{array}{l}\text { Leaf lobe posture } \\
\text { and surface }\end{array}$ & $\begin{array}{l}\text { Pendulous, surface } \\
\text { bullate (convex between } \\
\text { nerves) }\end{array}$ & Horizontal, surface flat & Unknown \\
\hline $\begin{array}{l}\text { Spadix male: } \\
\text { female zone width }\end{array}$ & $\begin{array}{l}\text { Base of male zone } \\
\text { abruptly wider than } \\
\text { female zone below }\end{array}$ & $\begin{array}{l}\text { Male zone about as wide } \\
\text { as female zone }\end{array}$ & $\begin{array}{l}\text { Male zone about as } \\
\text { wide as female zone }\end{array}$ \\
\hline Spathe length $(\mathrm{cm})$ & $(30-) 40-55(-70)$ & $24-30(-34.5)$ & 80 \\
\hline $\begin{array}{l}\text { Spathe tube: colour } \\
\text { of outer surface }\end{array}$ & $\begin{array}{l}\text { Uniformly yellow (or } \\
\text { white) }\end{array}$ & $\begin{array}{l}\text { Vertical broad pink-brown } \\
\text { stripes on white } \\
\text { background }\end{array}$ & Unknown \\
\hline $\begin{array}{l}\text { Spathe blade: } \\
\text { colour of inner } \\
\text { surface }\end{array}$ & $\begin{array}{l}\text { Yellow or white around } \\
\text { margins, central area } \\
\text { dark red-purple. } \\
\text { Demarcation abrupt }\end{array}$ & $\begin{array}{l}\text { Light reddish brown to } \\
\text { pink with pale green } \\
\text { veins, gradually slightly } \\
\text { darkening in the central } \\
\text { area }\end{array}$ & Unknown \\
\hline $\begin{array}{l}\text { Number of ovary } \\
\text { locules \& stigma } \\
\text { lobes }\end{array}$ & $2(-3)$ & $(2-) 3$ & 2 \\
\hline $\begin{array}{l}\text { Female flower } \\
\text { density }\end{array}$ & $\begin{array}{l}\text { Covering completely the } \\
\text { female zone spadix axis }\end{array}$ & $\begin{array}{l}\text { Lax (sparse), spadix axis } \\
\text { visible between the } \\
\text { female flowers }\end{array}$ & $\begin{array}{l}\text { Covering completely } \\
\text { the female zone } \\
\text { spadix axis }\end{array}$ \\
\hline $\begin{array}{l}\text { Female and male } \\
\text { flower zone } \\
\text { contiguity }\end{array}$ & $\begin{array}{l}\text { Female and male zones } \\
\text { contiguous, male and } \\
\text { female flowers in contact } \\
\text { with each other }\end{array}$ & $\begin{array}{l}\text { Female zone separated } \\
\text { from male zone by a sort } \\
\text { naked portion of spadix } \\
\text { axis }\end{array}$ & $\begin{array}{l}\text { Female and male } \\
\text { zones contiguous, } \\
\text { male and female } \\
\text { flowers in contact } \\
\text { with each other }\end{array}$ \\
\hline
\end{tabular}

12 


\section{Table 2 (on next page)}

Characters separating Anchomanes and Pseudohydrosme.

Data from Mayo et al. (1997); Bogner (1981); Cusimano et al. (2011); Hetterscheid \& Bogner (2014); this paper 
1

2 Table 2.

3 Characters separating Anchomanes and Pseudohydrosme.

4 Data from Mayo et al. (1997); Bogner (1981); Cusimano et al. (2011); Hetterscheid \& Bogner (2013);

5 Keating (2002); this paper.

6

\begin{tabular}{|l|l|l|}
\hline & Anchomanes & Pseudohydrosme \\
\hline $\begin{array}{l}\text { Spadix: spathe proportions and } \\
\text { presentation }\end{array}$ & $\begin{array}{l}\text { Spadix relatively long }>1 / 2- \\
9 / 10 \text { as long as spathe; } \\
\text { conspicuous, projected above } \\
\text { the (short) spathe tube }\end{array}$ & $\begin{array}{l}\text { Spadix relatively short, 1/10-1/4 as } \\
\text { long as spathe; completely } \\
\text { concealed within, and at base of the } \\
\text { (long) spathe tube }\end{array}$ \\
\hline Peduncle & $\begin{array}{l}\text { Peduncle exserted far beyond } \\
\text { cataphylls; 2-5 x length of } \\
\text { spathe }\end{array}$ & $\begin{array}{l}\text { Completely concealed at anthesis } \\
\text { by cataphylls; } \\
<1 / 10 \text { length of spathe }\end{array}$ \\
\hline $\begin{array}{l}\text { Ovary locularity and stigma } \\
\text { lobe number }\end{array}$ & 1 & 2 or 3 \\
\hline Berries & Sessile & Stipitate (where known) \\
\hline Laticifers & Present, simple, articulated & $\begin{array}{l}\text { Absent (not detected by Keating, } \\
\text { 2002) }\end{array}$ \\
\hline $\begin{array}{l}\text { Reproducing asexually from } \\
\text { roots }\end{array}$ & $\begin{array}{l}\text { Absent (but propagation from } \\
\text { root cuttings in cultivation } \\
\text { reported anecdotally) }\end{array}$ & Present \\
\hline
\end{tabular}

7

8 